The following document is a pre-print version of:

Ross P-S, Boulerice A, Mercier-Langevin P, McNicoll V (2019) Volcanology, chemo-stratigraphy, geochronology, hydrothermal alteration and VMS potential of the Lemoine Member of the Waconichi

Formation, Chibougamau district, Abitibi greenstone belt, Québec. Mineralium Deposita DOI 10.1007/s00126-

019-00884-6

\title{
Volcanology, chemo-stratigraphy, geochronology, hydrothermal alteration and VMS potential of the Lemoine Member of the Waconichi Formation, Chibougamau district, Abitibi greenstone belt, Québec
}

\author{
Pierre-Simon Ross ${ }^{1, *}$, Alexandre Boulerice ${ }^{1}$, Patrick Mercier-Langevin ${ }^{2}$, Vicki McNicoll ${ }^{3}$ \\ 1. Institut national de la recherche scientifique, 490 de la Couronne, Québec (QC), G1K 9A9, Canada \\ 2. Geological Survey of Canada, 490 de la Couronne, Québec (QC), G1K 9A9, Canada \\ 3. Geological Survey of Canada, 601 Booth St., Ottawa (ON), K1A 0E8, Canada \\ * Corresponding author, rossps@ete.inrs.ca
}

\begin{abstract}
The Archean Lemoine volcanogenic massive sulfide (VMS) deposit in the Chibougamau mining district (Abitibi greenstone belt) is one of the richest to have been mined in the world $(758,070 \mathrm{t}$ of ore at $4.17 \%$ $\mathrm{Cu}, 9.51 \% \mathrm{Zn}, 4.56 \mathrm{~g} / \mathrm{t} \mathrm{Au}$ and $83.73 \mathrm{~g} / \mathrm{t} \mathrm{Ag}$ ). It is hosted by the $2728 \mathrm{Ma}$ Lemoine Member of the Waconichi Formation. Field mapping, core logging, petrography, lithogeochemistry and U-Pb zircon geochronology helped define the stratigraphy, volcanic architecture, and hydrothermal history of the Lemoine Member east of the former mine, and document the complex relationships between effusive, intrusive and hydrothermal activity. There, the Lemoine Member is informally divided into a 700 to 900 m-thick lower part ( 45\% extrusive and $\sim 55 \%$ intrusive) and a 600 to $700 \mathrm{~m}$-thick upper part ( 85\% extrusive and $\sim 15 \%$ intrusive). Extrusive units in the lower part have a tholeiitic to transitional magmatic affinity and are dominantly felsic, whereas those of the upper part have a transitional to calc-alkaline affinity and are dominantly mafic. The effusive felsic units are mostly interpreted as one or more lobehyaloclastite flow(s) per unit. Possible volcanic vent sites for all effusive units were identified. Three types of hydrothermal alteration are present in the lower part of the Lemoine Member in the study area, from stratigraphic base to top: chlorite-sericite, sericite-chlorite and sericite-chlorite-carbonate \pm epidote. Within this broad pattern, three paleo-hydrothermal upflow zones are proposed, and some correspond with known base and precious metal anomalies and/or proposed volcanic vent locations.
\end{abstract}

\section{Introduction}

Volcanogenic massive sulfide (VMS) deposits are important sources of base $(\mathrm{Cu}, \mathrm{Zn} \pm \mathrm{Pb})$ and precious (Au, Ag) metals. The sulfides accumulate on the seafloor or just below it, and precipitate from hydrothermal fluids that circulate in the oceanic crust (Franklin et al. 2005; Galley et al. 2007). The heat source for fluid circulation is typically a synvolcanic intrusion, which can range from felsic to mafic (Maier et al. 1996; Galley 2003; Piercey et al. 2008; Hollis et al. 2015).
Volcanic rocks are typical in the host successions of VMS deposits (Gibson et al. 1999; Ross and MercierLangevin 2014), and these volcanic rocks can be used to vector towards mineralization in different ways. A common strategy is to use lithogeochemistry, and occasionally petrography, to study the hydrothermal alteration in the volcanic rocks, since alteration zones can have a larger footprint than the mineralization (Franklin 1997; Large et al. 2011; Gifkins et al. 2005).

A less commonly employed strategy is to map facies variations within the stratigraphy in order to locate 
volcanic vents and reconstruct the volcanic architecture of a prospective area (Gibson et al. 1999; Rogers et al. 2008; Debreil et al. 2018). The importance of locating volcanic vents, or at least identifying vent-proximal environments, is that volcanic vents may coincide with hydrothermal vents, the two being often controlled by syn-volcanic faults (Gibson et al. 1999). Before facies variations can be mapped within individual units, a detailed stratigraphy of the volcanic rocks has to be established, by combining primary textures, such as phenocrysts, and immobile element ratios (MacLean and Barrett 1993; Barrett and MacLean 1999; Rogers et al. 2008; Debreil et al. 2018). This detailed stratigraphic knowledge is also useful to follow prospective horizons laterally, since VMS deposits tend to occur at specific stratigraphic positions within a district (Franklin et al. 2005; Galley et al. 2007) that are often, but not always, manifested by thin "marker" horizons referred to as iron formations, exhalites, or tuffites, depending on their compositions.

The Chibougamau mining district is located in the northern Abitibi greenstone belt of Québec, Canada. Only two significant VMS deposits, Lemoine and Scott Lake, are known so far in the Chigougamau district. Further west, the Matagami district, which has a very similar geology and age, contains 20 known VMS deposits, including the Mattagami Lake (Roberts 1975) and Bracemac-McLeod deposits (Genna et al. 2014; Debreil et al. 2018).

Lemoine was one of the richest VMS deposits in terms of total net smelter return of $\mathrm{Au}, \mathrm{Cu}, \mathrm{Zn}$ and $\mathrm{Ag}$ in Canada and the world $(758,070 \mathrm{t}$ of ore at $4.17 \% \mathrm{Cu}$, 9.51\% Zn, $4.56 \mathrm{~g} / \mathrm{t} \mathrm{Au}$ and 83.73 g/t Ag; Riverin 2003; Lafrance and Brisson 2006; Mercier-Langevin et al. 2014). The gold grade is high for a VMS deposit, meaning that Lemoine classifies in the "auriferous" category (Mercier-Langevin et al. 2011). Both Lemoine and Scott Lake are hosted by felsic tholeiitic members of the Waconichi Formation (Daigneault and Allard 1990; Leclerc et al. 2012). A better knowledge of the volcanic, stratigraphic and hydrothermal architecture of these members would facilitate future VMS exploration in the Chibougamau district. It would also bring light on the immediate volcanic/subvolcanic architecture of the Lemoine mine host succession and provide further information about this unusually Au-rich VMS deposit.

The stratigraphy and hydrothermal alteration in the area adjacent to the former Lemoine mine is well understood (Lafrance and Brisson 2006; Mercier-Langevin et al. 2014; Ross et al. 2016). However, further east in the Lemoine Member of the Waconichi Formation, there are knowledge gaps that limit our understanding of the overall context in which the exceptionally precious and base metal-rich Lemoine VMS deposit formed. This hampers the development of improved exploration models that would incorporate the key elements associated with the Lemoine VMS deposit. Rock units of ambiguous origin, either volcanic or intrusive, are present. Moreover, no comprehensive study of the hydrothermal alteration in the area east of the Lemoine deposit exists, which further complicates vectoring towards potential mineralized zones. The area east of the former mine was therefore chosen as a study area.

The main objectives of this study were to: (1) geochemically and texturally define units of the Lemoine Member, east of the former mine, (2) determine the emplacement processes associated with each unit, (3) provide a model for the volcanic architecture of the lower part of the Lemoine Member, and (4) characterize the alteration assemblages and provide an understanding of their spatial distribution in relation to the volcanic architecture. This information will provide further constraints that will help vector toward potential mineralized zones in the study area and in similar settings elsewhere. In the discussion, we highlight the importance of lobe-hyaloclastite lava flows in Archean VMS districts.

\section{Geological context \\ Chibougamau district}

The Chibougamau district is located in the NE portion of the Archean Abitibi greenstone belt (Superior Province, eastern Canada) (Figs. 1a, 1b). The Archean stratigraphy of the Chibougamau area comprises two major volcano-sedimentary packages, the 2731 to $<2721 \mathrm{Ma}$ Roy Group and the overlying <27062688.5 Ma Opémisca Group (Daigneault and Allard 1990; David et al. 2007; Leclerc et al. 2011, 2012) (Fig. 1c). These volcanic and sedimentary rocks are cross-cut by the 5-7 km-thick Lac Doré Complex (LDC), a mafic layered intrusive complex (Daigneault and Allard 1990) dated 2728.3 +1.2/-1.1 Ma (Mortensen 1993), as well as by 2720 to 2695 Ma (Joanisse 1998; Mortensen 1993; David et al. 2011) granitic intrusions including the Chibougamau Pluton, by Archean gabbroic intrusions (e.g., Bédard et al. 2009), and by Proterozoic mafic dykes.

The Roy Group includes two successions of mafic to felsic volcano-sedimentary rocks representing two cycles of volcanism. The first cycle consists of a 3-4 km-thick tholeiitic basaltic plateau, the Obatogamau Formation, composed of massive and pillowed flows and associated mafic dykes and sills (Pilote 1998; Leclerc et al. 2011). The end of the first cycle consists of the Waconichi Formation, that in the traditional definition comprises mostly felsic to intermediate volcanic rocks (Daigneault and Allard 1990), including 
those that host the Scott Lake and Lemoine VMS deposits. The Waconichi Formation has been expanded to include mafic, intermediate and felsic rocks of tholeiitic to calc-alkaline affinity (Leclerc et al. 2012; Fig. 1c). The expanded Waconichi Formation has been dated at 2731-2726 Ma (Mortensen 1993; Leclerc et al. 2011).

The second cycle of the Roy Group consists of the Bruneau Formation, composed of tholeiitic massive and pillowed basalt and basaltic andesite flows (Leclerc et al. 2011); the $\leq 1 \mathrm{~km}$-thick, $\sim 2721$ Ma Blondeau Formation, composed of tholeiitic rhyolitic and basaltic flows overlain by calc-alkaline volcaniclastic rocks and volcanic-derived sedimentary units (Daigneault and Allard 1990; Leclerc et al. 2011, 2012); and by the Bordeleau Formation, composed of lithic and immature sandstones and mudstones (Allard et al. 1985; Daigneault and Allard 1990; Moisan 1992).

Uplift and erosion of the Roy Group volcanic rocks is responsible for the unconformity that separates it from the Opémisca Group. The latter is divided into the $<2704 \pm 2 \mathrm{Ma}$ Stella Formation conglomerates, feldspathic sandstones and argillites (Daigneault and Allard 1990; Leclerc et al. 2012), and the overlying $>2691.7 \pm 2.9$ Ma Haüy Formation, composed of sedimentary rocks and K-rich andesites (Allard and Gobeil 1984; David et al. 2007).

Volcanic and sedimentary rocks have been affected by several stages of deformation during the Archean and the Proterozoic (Daigneault and Allard 1990; Chown et al. 1992; Cote-Mantha et al. 2012). Metamorphism is typically of greenschist facies but locally reaches amphibolite facies in proximity of some plutons and large intrusions (Daigneault and Allard 1990). Metamorphic grade also increases with proximity of the Grenville front (Daigneault and Allard 1990).

The Chibougamau district is well known for its "Chibougamau type" $\mathrm{Cu}-\mathrm{Au}$ vein deposits (Pilote 1998). These deposits are synvolcanic with the first volcanic cycle in the Roy Group and predate major deformation events (Leclerc et al. 2012). The LDC hosts layered-style $\mathrm{Fe}-\mathrm{Ti} \pm \mathrm{V}$ magmatic deposits in association with magnetite-rich layers of the Layered Series (Allard 1976; Daigneault and Allard 1990; Leclerc et al. 2012). Epithermal-style and mesothermal gold deposits have also been described in the region (Guha et al. 1988; Dubé and Guha 1992; Pilote 1998; Coté-Mantha et al. 2012). Epithermal-style deposits are interpreted to be synvolcanic with the second volcanic cycle of the Roy Group, whereas mesothermal shear zone-hosted deposits are spatially associated with E-W shear zones and N-E faults (Guha et al. 1988; Dubé and Guha 1992; Leclerc et al. 2012).

The Lemoine (Patel et al. 1977; Donahue 1982; Lafrance and Brisson 2006; Mercier-Langevin et al. 2014) and Scott Lake (Saunders and Allard 1990; Carignan 2010; Salmon 2010; Salmon and McDonough 2011) VMS deposits are both hosted by the Waconichi Formation. Lemoine and Scott Lake are classified as bimodal-mafic VMS deposits (Barrie and Hannington 1999; Franklin et al. 2005; Galley et al. 2007). Lemoine was mined over the period 1975-1983, producing $758,070 \mathrm{t}$ of ore at $4.17 \% \mathrm{Cu}, 9.51 \% \mathrm{Zn}, 4.56 \mathrm{~g} / \mathrm{t} \mathrm{Au}$ and $83.73 \mathrm{~g} / \mathrm{t} \mathrm{Ag} \mathrm{(Mercier-Langevin} \mathrm{et} \mathrm{al.} \mathrm{2014).} \mathrm{Scott}$ Lake is an exploration project with indicated mineral resources of 3.6 Mt averaging $1.0 \% \mathrm{Cu}, 4.2 \% \mathrm{Zn}, 37 \mathrm{~g} / \mathrm{t}$ $\mathrm{Ag}$, and $0.2 \mathrm{~g} / \mathrm{t} \mathrm{Au}$ and inferred mineral resources of 14.3 Mt averaging $0.8 \% \mathrm{Cu}, 3.5 \% \mathrm{Zn}, 22 \mathrm{~g} / \mathrm{t} \mathrm{Ag}$, and $0.2 \mathrm{~g} / \mathrm{t} \mathrm{Au}$ (Roscoe and Masun 2017).

\section{Lemoine Member}

The Lemoine VMS deposit is located in the Lemoine Member of the Waconichi Formation, within volcanic cycle 1 of the Roy Group. The Lemoine Member forms a $\geq 20 \mathrm{~km}$-long, NE-SW trending volcanic package (Daigneault and Allard 1990; Lafrance and Brisson 2006) (Figs. 1c, 2). It includes dominantly felsic, tholeiitic to transitional volcanic rocks at its base followed by dominantly mafic, transitional to calcalkaline volcanic rocks at its top. Two felsic units from the lower part of the Lemoine Member were dated by $\mathrm{U}-\mathrm{Pb}$ on zircons by Mortensen (1993), using outcrops near Lake Yvette (Fig. 2): the Hangingwall quartz and feldspar porphyry (HwQFP) at 2729.7+1.9/-1.6 Ma and the Marelle quartz and feldspar porphyry (Marelle QFP) at $2728.0+1.5 /-1.4 \mathrm{Ma}$. The upper part of the Lemoine Member consists mostly of transitional to calc-alkaline basalts formerly assigned to the Gilman Formation (Morin 1994). The $5 \mathrm{~km}$-long by $1 \mathrm{~km}$-wide study area includes the entire lower part of the Lemoine Member, and the base of the upper part, east of the former Lemoine mine (Fig. 2).

\section{Methods \\ Field methods}

Over the course of two field seasons, 145 outcrops were studied, six were mapped in detail $(\sim 1: 100$ to $1: 200$ scale), and core from 18 diamond drill holes (DDH) totalling about 13,500 metres was relogged (Boulerice 2016). Field work focussed on stratigraphy, physical volcanology, and hydrothermal alteration assemblages. Volcanic textures and lithofacies were mapped to elucidate the mode of emplacement for each unit. Study of lateral thickness and facies variations was also utilized to locate volcanic vents. 


\section{Lithogeochemistry}

Lithogeochemistry is useful both for chemostratigraphy and to map hydrothermal alteration. A total of 283 representative drill core $(20-30 \mathrm{~cm}$ long, 3.7 to $4.8 \mathrm{~cm}$ diameter) and outcrop samples were analyzed by Activation Laboratories in Ancaster, Ontario, Canada, for major and trace elements. Samples were first crushed and pulverized using mild steel, mixed with a lithium metaborate and lithium tetraborate flux, and fused by melting. The melts were dissolved in acid and analyzed by ICP-AES for major oxides and some trace elements (Ba, Be, Sc, Sr, V, Y and Zr) and by ICP-MS for 44 trace elements (ESM1). The following reference materials were used for quality control: GSJ JR-1, ICHT CTA-AC-1, NCS DC70009 (GBW07241), NCS DC70014, NCS DC86312, NIST 694, NRCan LKSD-3, OREAS 100a, OREAS 101a, USGS BIR-1a, USGS DNC-1a, and USGS W-2a. In addition, the following reference materials were used for one or two session(s): GBW 07113, NCS DC73372, NRCan SY-4, NRCan TDB-1, SARM 3, SARM ZW$\mathrm{C}$, and USGS BCR-2. For major oxides, at the concentrations typically found in volcanic rocks, data accuracy was typically better than $5 \%$ (relative difference), and always better than $10 \%$. The exception was $\mathrm{P}_{2} \mathrm{O}_{5}$, for which the accuracy was sometimes poor, but this oxide is not used in this study. For the rare earth elements, as well as $\mathrm{Nb}$ and $\mathrm{Th}$, accuracy was often better than 5\%, and always better than $10 \%$. For Hf, Ta, $\mathrm{Y}$ and $\mathrm{Zr}$, accuracy was typically better than $10 \%$. For $\mathrm{V}$, accuracy was better than $15 \%$ at the concentrations typical of mafic rocks (this element was not used for felsic rocks). Other trace elements were not used in this study. To give a measure of reproducibility, 6 to 12 duplicates were run for each session. The relative difference between original and repeat analyses was typically less than $5 \%$ for major oxides, with the exception of $\mathrm{P}_{2} \mathrm{O}_{5}$, and for the trace elements used in this study.

Added to the collected samples are 537 analyses of volcanic and intrusive rocks (excluding minor dikes) from Cogitore Resources' database within the study area. However, most of these company analyses do not include the full suite of trace elements. We therefore used the legacy analyses only to calculate alteration indices, as well as in plots and tables involving major oxides, $\mathrm{Nb}, \mathrm{Y}$, and $\mathrm{Zr}$.

\section{Hydrothermal alteration}

Outcrop, drill core and petrographic (91 thin sections) observations were used to describe and map different alteration assemblages and their distribution to identify potential hydrothermal upflow zones. These direct mineralogical observations are complemented by laboratory-based lithogeochemistry and a portable XRF profile (ESM2). Two alteration indices were calculated based on major oxides, using the laboratory-based geochemistry: the Hashimoto alteration index (AI, Ishikawa et al. 1976) and the chlorite-carbonate-pyrite index (CCPI, Large et al. 2001), where AI = $100 *\left(\mathrm{~K}_{2} \mathrm{O}+\mathrm{MgO}\right) /\left(\mathrm{K}_{2} \mathrm{O}+\mathrm{MgO}+\mathrm{CaO}+\mathrm{Na}_{2} \mathrm{O}\right)$ and $\mathrm{CCPI}$ $=100 *\left(\mathrm{FeO}^{\mathrm{t}}+\mathrm{MgO}\right) /\left(\mathrm{FeO}^{\mathrm{t}}+\mathrm{MgO}+\mathrm{Na}_{2} \mathrm{O}+\mathrm{K}_{2} \mathrm{O}\right)$, where $\mathrm{FeO}^{\mathrm{t}}$ is total iron. Both indices are influenced by the destruction of volcanic glass and plagioclase, and by the addition of Mg-rich chlorite. AI is also influenced by sericite, whereas CCPI is also sensitive to Fe-chlorite, pyrite, iron oxides, and some carbonates, as well as to the primary compositions of the rocks.

Precious and base metal anomalies were located to evaluate a spatial correlation with hydrothermal upflow zones and favourable stratigraphic units or horizons, using assays from Cogitore Resources.

\section{U-Pb geochronology}

Three coherent (massive) samples from felsic units were dated. The Alpha rhyolite in the Western sector was sampled in DDH LEM-18 from $154.36 \mathrm{~m}$ to $169.40 \mathrm{~m}$ downhole depth (Fig. 2). The Lemoine rhyolite was sampled near the former Lemoine mine in DDH LEM-40 from $567.5 \mathrm{~m}$ to $590.8 \mathrm{~m}$ downhole depth. Finally, the Marelle QFP was taken from a large outcrop north of Lake Yvette, at $565314 \mathrm{~m} \mathrm{E}$, $5513841 \mathrm{~m} \mathrm{~N}$ (UTM Nad 83, zone 18), most likely at the same location sampled by Mortensen (1993), because we wanted to increase the precision of this age and use single grain fractions.

$\mathrm{U}-\mathrm{Pb}$ isotope dilution-thermal ionization mass spectrometry (ID-TIMS) was performed at the Geological Survey of Canada in Ottawa. Analytical methods utilized in this study are modified after Parrish et al. (1987). Treatment of analytical errors follows Roddick (1987), with regression analysis modified after York (1969). Heavy mineral concentrates were prepared by standard crushing, grinding, Wilfley table, and heavy liquid techniques. Mineral separates were sorted by magnetic susceptibility using a Frantz ${ }^{\mathrm{TM}}$ isodynamic separator and were handpicked using a binocular microscope. All analyses are of single zircon grains that have been chemically abraded, following the techniques of Mattinson (2005), including annealing for 48 hours at $1000^{\circ} \mathrm{C}$ prior to leaching with $\mathrm{HF}$ at $180^{\circ} \mathrm{C}$ for varying lengths of time. Procedural $\mathrm{Pb}$ blanks for analyses in this study are generally $1 \mathrm{pg}$ or less. All age uncertainties are presented at the $2 \sigma$ level.

\section{Stratigraphy of the Lemoine Member}

The detailed stratigraphy of the Lemoine Member in the study area has been refined based on field work and lithogeochemistry. Volcanic units dip steeply between 
$70^{\circ}$ and $80^{\circ}$ towards the SE (Fig. 3). The stratigraphic younging direction is also towards the SE. The study area is subdivided here into the Western, Raft and Eastern sectors (Fig. 2). In the three sectors, the Marelle QFP (intrusive) is a thick unit in the lower part of the Lemoine Member, immediately south of the LDC. In all three sectors, the felsic-dominated lower part of the Lemoine Member is stratigraphically overlain by the thick transitional basalt (extrusive) of the upper part of the Lemoine Member. Underneath this transitional basalt is the HwQFP (extrusive, sometimes called "TxGil" in previous studies), which pinches out eastward. The stratigraphy of the lower part of the Lemoine Member varies significantly from one sector to the next, as detailed below.

The Raft sector contains a $>1 \mathrm{~km}$-long and approximately $50 \mathrm{~m}$-thick Lemoine rhyolite enclave or "raft" within the Marelle QFP (Fig. 2). The Lemoine rhyolite is extrusive here. The Lemoine rhyolite raft is surrounded by a partial rim of Alpha rhyolite (called the "high-Zr Marelle QFP" in previous studies), interpreted as intrusive, and younger than the Lemoine rhyolite in the Raft sector. Further up in the stratigraphy, a thin layer of Lemoine dacite (extrusive) overlies the Lemoine rhyolite and is followed by the relatively thick Lemoine andesite (extrusive). The Coco Lake QFP (previously the "Upper-Lemoine rhyolite") forms two sill-like intrusions.

In the Western sector, the oldest extrusive unit is the Alpha rhyolite, here texturally different from that of the Raft sector. The Lemoine rhyolite overlies the Alpha rhyolite (Fig. 3). The Lemoine dacite is absent and thus the Lemoine andesite is in direct contact with the Lemoine rhyolite.

In the Eastern sector, the lower part of the Lemoine Member is only represented by the Lemoine dacite and the Lemoine andesite. The Marelle QFP intrudes at several stratigraphic levels in the Lemoine Member.

\section{Volcanology of extrusive units}

Six extrusive units occur within the Lemoine Member in the study area. They are, from oldest to youngest, the Alpha rhyolite in the Western sector, the Lemoine rhyolite, the Lemoine dacite, the Lemoine andesite, the HwQFP and the transitional basalt (Boulerice 2016). The thickness ranges, main lithofacies, textures, and petrography for each unit are given in Table 1. Volcanic facies variations were examined for five units, four of which are shown in Fig. 4, and discussed below. In the transitional basalt, no analysis of volcanic facies proportions was made. It is composed of massive and pillowed facies where individual pillows are typically separated by thin hyaloclastite bands.

\section{Alpha rhyolite in the Western sector}

In the Western sector, the Alpha rhyolite dominantly contains coherent ("massive") facies with accompanying lobate, and hyaloclastite facies (Figs. 4, $5 a, 5 b)$. Lobes have of a coherent interior whereas the margins commonly contain stretched amygdales, but lack preserved flow banding. Lobe margins often sharply transition into other lobes or into hyaloclastite (Fig. 5b). Lobe borders can be difficult to distinguish in drill core because of the abundance of cross-cutting mafic dykes, and chlorite alteration. Thus, lobate and massive facies have been grouped together, representing over $90 \%$ of the observed drill core in each DDH from the Western sector (LEM-15 and LEM-18 on Fig. 4). Although minor at $\leq 5 \%$, hyaloclastite is defined by well-preserved, but often stretched fragments (Fig. 5b). This facies is more abundant towards the top of the unit. In the Raft sector, the Alpha rhyolite is interpreted as intrusive, is described below.

\section{Lemoine rhyolite}

The Lemoine rhyolite forms the immediate footwall of the Lemoine VMS deposit (Donahue 1982; MercierLangevin et al. 2014). It extends $10 \mathrm{~km}$ along strike from SW of the former mine site to the Raft sector in the northeast (Fig. 2). It reaches a thickness of $\sim 460 \mathrm{~m}$ some $0.5 \mathrm{~km}$ to the $\mathrm{W}$ of the Lemoine deposit (Ross et al. 2014a, Fig. 2). Within the study area it is thickest in the Western sector, reaching $200 \mathrm{~m}$ (Fig. 3), and it thins eastward to $\sim 75 \mathrm{~m}$ in the Raft sector, including the $\sim 50$ m-thick raft.

In the study area, the Lemoine rhyolite is dominated by coherent (massive) zones, which locally display polygonal joints (Fig. 5c), and lobes (Figs. 5d, 5e). Stretched amygdales are present near lobe margins. A lesser proportion of hyaloclastite is also present within the Lemoine rhyolite in the study area, with a westward increase (Fig. 4). Approximately $850 \mathrm{~m}$ west of the Lemoine mine, outcrops display meter scale lobes separated by angular hyaloclastite (Fig. 5f), indicating an effusive origin. Near the mine, the Lemoine rhyolite hosts a thin tuffaceous horizon halfway up the unit (Mercier-Langevin et al. 2014).

\section{Lemoine dacite}

The Lemoine dacite is present in the Raft and Eastern sectors where it extends from DDH LEM-52 to the edge of the study area to the NE (Fig. 2). The Lemoine dacite ranges from massive and spherulitic to hyaloclastite. The latter facies is characterized by elongated angular fragments. The spatial distribution of volcanic facies in the Lemoine dacite is highly variable (not shown here, see Boulerice 2016). Taken as a whole, the unit contains more massive facies than hyaloclastite. 


\section{Lemoine andesite}

The Lemoine andesite forms a lava unit that extends from the Lemoine mine (and even west of it in some cross-sections, see Ross et al. 2016) to the northeast termination of the Lemoine Member (Fig. 2). The Lemoine andesite is thickest in the Raft sector and systematically decreases in thickness with distance from the center of the study area (Fig. 2). The Lemoine andesite consists predominantly of massive flows with lesser pillowed flows (Fig. 5g). Hyaloclastite forms up to a few tens of percent of the rocks.

Individual pillows can be difficult to distinguish because of deformation and alteration. Massive and pillow-lava proportions have been grouped together in drill holes where their identification was ambiguous. The proportion of hyaloclastite and pillow facies (where available) generally increases with distance from DDH LEM-49, situated near the centre of the study area (Fig. 4).

Hangingwall quartz and feldspar porphyry (HwQFP) In the mine area, the HwQFP sits directly on top of the Lemoine rhyolite (Fig. 2). There, it forms the immediate hangingwall to VMS mineralization of the Lemoine deposit (Mercier-Langevin et al. 2014). In the study area, the HwQFP sits on top of the Lemoine andesite, is up to 120 m-thick in the Western sector (Fig. 3), and from there it gradually thins to the northeast where it eventually disappears (Fig. 4). Feeder dykes of HwQFP composition and texture are present in the Western sector.

The HwQFP is mostly coherent (massive) with minor hyaloclastite (Figs. 4, 6a, 6b). The proportion of hyaloclastite is extremely low to absent in the study area (Fig. 4), with the exception of DDH LEM-31 that intersects a local zone of hyaloclastite. West of the study area, near the former Lemoine mine, the HwQFP consists of amygdaloidal lobes (Fig. 6c) and associated volcaniclastic strata (Donahue 1982; Mercier-Langevin et al. 2014). In the mine area, the top of the HwQFP has been described as fining upwards and transitioning into a finely laminated tuff (Mercier-Langevin et al. 2014).

\section{Transitional basalt}

The upper part of the Lemoine Member is dominated by a thick sequence of the transitional basalt (Fig. 2). The overall thickness of this unit is unknown in the study area but is at least $300 \mathrm{~m}$ thick. Although no analysis of volcanic facies proportions was made for the transitional basalt, the unit is composed essentially of massive (Fig. 6d) and pillowed facies.

\section{Intrusive units \\ Felsic units}

Five felsic intrusive units have been defined in the study area: the Alpha rhyolite in the Raft sector (Fig. 6e), the Coco Lake QFP (Fig. 6f), the Marelle QFP (Fig. 6g), the dacitic porphyry (not shown), and the Gold Hill tonalite (Fig. 6h). The first four are interpreted as forming multiple sills (Boulerice 2016), intruding at different positions within the lower part of the Lemoine Member (Fig. 2). These four units all have a porphyritic texture with an aphanitic groundmass, but the proportion and size of phenocrysts varies (Table 1), and so does the bulk rock chemistry (see next section). The Marelle QFP forms the thickest, and most laterally persistent, sills, especially the one at the base of the volcanic pile, in contact with the LDC (Fig. 2). All of these felsic intrusions, as well as some gabbros, considerably thicken the lower part of the Lemoine Member, making it approximately $\sim 45 \%$ extrusive and $\sim 55 \%$ intrusive.

The Alpha rhyolite is clearly intrusive in the Raft sector, unlike in the Western sector. In the Raft sector, the Alpha rhyolite cross-cuts the Lemoine rhyolite based on its distribution at several apparent stratigraphic positions (Fig. 2). Other evidence of an intrusive origin includes the uniformly coherent textures, and specific observations on stripped outcrops, including enclaves of Lemoine rhyolite within the Alpha rhyolite (Fig. 6e), very close to the contact between the two units. This indicates that the Lemoine rhyolite was emplaced first, and was then incorporated as clasts in the intrusive Alpha rhyolite.

The Gold Hill tonalite is different from the other felsic intrusive units, with a discordant orientation at high angle to structural fabric, phaneritic texture, and abundant feldspar. It may be related of the Chibougamau pluton (Boulerice 2016).

\section{Gabbro and diorite}

Various gabbros and diorites are present in the study area ("gabbro" on Fig. 2), but they were not studied in detail, and are not included in the following section on geochemistry. In the mine area, the Lemoine diorite is a volumetrically important intrusive unit (MercierLangevin et al. 2014; Ross et al. 2014a).

\section{Geochemistry: lithological discrimination}

Ratios of typically immobile elements such as $\mathrm{Al}, \mathrm{Nb}$, $\mathrm{Ti}, \mathrm{Th}, \mathrm{V}, \mathrm{Y}, \mathrm{Yb}$, and $\mathrm{Zr}$, were essential to discriminate the various Lemoine Member volcanic and intrusive units and follow them laterally. Variably mobile elements such as Fe, La and $\mathrm{Si}$ were also utilized where needed. The main diagrams used in this study to name and discriminate rocks were the Winchester and Floyd 
(1977) classification diagrams (Figs. 7a, 7b), the Ross and Bédard (2009) magmatic affinity diagrams (Fig. 7c), a Ti/Al versus Al/Zr diagram (Fig. 7d), and extended trace elements plots (Fig. 8). The geochemical characteristics of Lemoine Member units are summarized in Table 2.

The dacitic porphyry and the Gold Hill tonalite come late in the sequence of volcanic and intrusive events, since they cross-cut all other rock types (Fig. 2). If these two units are excluded, the Lemoine Member forms a bimodal, mafic-felsic, succession. There is a temporal evolution in magmatic affinity from the lower part of the Lemoine Member, which is tholeiitic to transitional, to the upper part, which is mostly transitional to calcalkaline (Fig. 7c), as also shown by higher average $\mathrm{Zr} / \mathrm{Y}, \mathrm{Th} / \mathrm{Yb}$ and $\mathrm{La} / \mathrm{Lu}$ in the upper part (Table 2).

On the Agrawal et al. (2008) diagram, the Lemoine andesite plots in the mid-ocean ridge basalt (MORB) field, whereas the transitional basalt straddles the MORB and island arc basalt fields (Fig. 7e). On the Hart et al. (2004) fertility diagram, felsic units from the lower part of the Lemoine Member plot in the FIIIb field or nearby, whereas the HwQFP from the upper part of the Lemoine Member plots mostly in the FIIIa field, at significantly lower Yb values (Fig. 7f).

\section{Geochronology}

$\mathrm{U}-\mathrm{Pb}$ ID-TIMS analytical results are presented in Table 3 , along with details of zircon morphology, quality, and abrasion time. Results are further displayed in concordia plots (Fig. 9).

\section{Alpha rhyolite in LEM-18 (z11084)}

The dated sample is a quartz-phyric $(5-7 \%, 2 \mathrm{~mm})$, locally amygdaloidal rhyolite, moderately altered to chlorite and sericite. The zircons from this sample were $\sim 100-200 \mu \mathrm{m}$, clear, colourless, euhedral prisms to elongate prisms, with inclusions and fractures. Seven single-grain fractions, chemically abraded for 20 hours, were analyzed and yielded concordant to slightly discordant data. A linear regression of all the analyses, with a lower intercept at the origin, has an upper intercept of $2728.4 \pm 0.7 \mathrm{Ma} \quad(\mathrm{MSWD}=0.38$ ), interpreted as the crystallization age of the Alpha rhyolite.

\section{Lemoine rhyolite in LEM-40 (z10760)}

The dated sample is a quartz-phyric $(5-7 \%, 1-2 \mathrm{~mm})$ rhyolite, moderately altered to chlorite and sericite, with no visible sulfides. Zircon grains retrieved from this sample ranged in size from $\sim 50-175 \mu \mathrm{m}$, and were clear, colourless, euhedral prisms with fractures and few inclusions. Six single-grain zircon fractions were chemically abraded for 10-16 hours and yielded concordant to near concordant analyses. A weighted mean of the ${ }^{207} \mathrm{~Pb} /{ }^{206} \mathrm{~Pb}$ ages of all six fractions is calculated to be $2727.7 \pm 1.0 \mathrm{Ma}(\mathrm{MSWD}=0.8)$, which is interpreted as the crystallization age of the Lemoine rhyolite.

\section{Marelle QFP north of Lake Yvette (z10988)}

The sample is a quartz-phyric $(5-7 \%, \leq 3 \mathrm{~mm}$, blue) and feldspar-phyric $(10-15 \%, \leq 3 \mathrm{~mm})$ rock, with a finely crystalline groundmass, and trace sulfides. The zircons from this sample included clear, colourless, euhedral prisms to stubby prisms, with prominent fractures and few inclusions, and ranging in size from $\sim 100-200 \mu \mathrm{m}$. Six single-grain fractions, chemically abraded for 16-20 hours, were analyzed and yielded overlapping concordant data. A weighted mean of their ${ }^{207} \mathrm{~Pb} /{ }^{206} \mathrm{~Pb}$ ages is calculated at $2727.5 \pm 0.6 \mathrm{Ma}(\mathrm{MSWD}=0.07)$ and interpreted as the crystallization age of the Marelle QFP.

\section{Hydrothermal alteration and mineralization Alteration indices and downhole geochemical profile} In the study area, portions of the Lemoine rhyolite and part of the Alpha rhyolite in the Western sector have undergone significant hydrothermal alteration. This is shown by a number of analyzed samples plotting near the chlorite pole on the alteration box plot of Large et al. (2001) for these units (Fig. 10a). A distinct trend towards the sericite pole exists for the Lemoine rhyolite samples. By contrast, other extrusive and intrusive units in the Lemoine Member are mostly weakly altered to unaltered, or show low-temperature alteration (Fig. 10b). To show the spatial variations in alteration, gridded AI values are displayed on a map in ESM2. To document the contrast in alteration signatures between different lithological units, a profile of major oxides, AI and CCPI as a function of depth is included for one drill hole in ESM2.

\section{Alteration assemblages}

Three different alteration mineral assemblages have been defined (Boulerice 2016). These are, from stratigraphic bottom to top, (1) chlorite-sericite; (2) sericite-chlorite; and (3) sericite-chloritecarbonate \pm epidote (Fig. 11a). Quartz is stable in all of these assemblages.

Chlorite-sericite alteration occurs in the Alpha rhyolite (Western sector only), in the Lemoine rhyolite in the Raft sector, and locally in the Lemoine andesite in the Western sector (Fig. 11a), mostly at the lowest stratigraphic levels in the Lemoine Member. This assemblage is characterized by high AI and CCPI values. In thin section, chlorite is oriented parallel to the main foliation plane (Fig. 12a). Smaller ( $\leq 5 \mu \mathrm{m})$, less abundant, sericite crystals are distributed 
homogenously throughout the groundmass and included within large micropoikilitic feldspar phenocrysts. Larger sericite grains occur with chlorite along foliation planes (Fig. 12b).

Sericite-chlorite alteration occurs in most of the Lemoine rhyolite, both in the Western and the Raft sectors (Fig. 11a). It is also present locally in the Coco Lake QFP. The sericite-chlorite assemblage is characterized by variable AI and moderate CCPI values. In thin section, fine $(\leq 10 \mu \mathrm{m})$ sericite is abundant and widespread (Fig. 12c-d).

The sericite-chlorite-carbonatetepidote assemblage is preferentially developed in the uppermost part of the felsic volcanic package that includes the HwQFP and the intrusions at that stratigraphic level (Figs. 11a, 12e, 12f). This assemblage is also developed in the Lemoine dacite in the Raft sector. It is mostly associated with albite-epidote-carbonate (calcite) trends on the alteration box plot (Fig. 10).

\section{Metal anomalies and "exhalites" in the study area}

The Lemoine VMS deposit was located between the Lemoine rhyolite and the HwQFP. Drilling in the study area has mostly targeted the same horizon, and no new deposits have been identified thus far. However, the $\mathrm{Zn}$ $\mathrm{Cu}-\mathrm{Au}-\mathrm{Ag}$ metal anomalies that have been found at various positions in the Lemoine Member indicate that several stratigraphic levels are prospective. For simplicity, Figure 11b locates drill core intercepts with $\mathrm{Zn} \geq 0.5 \%, \mathrm{Cu} \geq 0.25 \%$, or $\mathrm{Au}>0.1 \mathrm{~g} / \mathrm{t}$.

Two potential hydrothermal upflow zones are associated with the Lemoine andesite. The first is located in the Western sector and is associated with $\mathrm{Zn}$ values in DDH LEM-49 (3.19\% Zn over $1.25 \mathrm{~m}$ and $1.29 \% \mathrm{Zn}$ over $2.0 \mathrm{~m}$ ) and $\mathrm{Cu}, \mathrm{Au}$ and $\mathrm{Ag}$ anomalies in DDH LEM-50 (e.g., 0.74\% Cu and $0.32 \mathrm{~g} / \mathrm{t} \mathrm{Au} \mathrm{over}$ $0.81 \mathrm{~m}$ ) (Fig. 11b). The second is associated with DDH LEM-60 in the Raft sector where anomalous $\mathrm{Cu}$, Au and Ag are present $(0.89 \% \mathrm{Cu}$ over $0.5 \mathrm{~m})$. Apart from these two areas, anomalous $\mathrm{Zn}$ values are present in the Lemoine andesite in DDH LEM-15 (0.67\% Zn over 1.5 $\mathrm{m})$, and anomalous values of $\mathrm{Cu}, \mathrm{Au}$ and $\mathrm{Ag}$ are locally found higher up in the stratigraphy in the transitional basalt (e.g., $0.46 \mathrm{~g} / \mathrm{t}$ Au over $0.5 \mathrm{~m}$ in DDH LEM-60) (Fig. 11b).

Thin layers of fine-grained silica-rich material and laminated tuff, sometimes with sulfides, occur in the study area. These layers are assumed to originate, at least in part, from exhalative processes associated with hydrothermal activity. Spatial analysis of these exhalative horizons has demonstrated an association with the stratigraphic top of both the Lemoine andesite and of the HwQFP (Figs. 11c, 11d). Donahue (1982) and Mercier-Langevin et al. (2014) also identified a thin layer of laminated tuff at the top of the HwQFP to the WSW of the Lemoine deposit. In the study area, these horizons are not laterally extensive but the intrusive Coco Lake QFP, at the same stratigraphic position, could be a factor in their preservation.

\section{Discussion}

\section{Submarine lava flows and location of volcanic vents}

Felsic lavas

Two effusive felsic units in the lower part of the Lemoine Member - the Alpha rhyolite in the Western sector and the Lemoine rhyolite - are interpreted as one or more lobe-hyaloclastite flows (Gibson et al. 1999). This is because (i) they are relatively widespread given their thicknesses, and (ii) massive and lobate facies dominate, with a much smaller proportion of hyaloclastite. In lobe-hyaloclastite flows, ventproximal areas correspond to the maximum flow thickness and maximum proportions of massive facies, whereas distal areas are the thinnest, and contain the most hyaloclastite (Gibson et al. 1999).

Although drill core gives access to the third dimension, the density of drill holes in the study area is not enough to map thickness and facies variations in 3D. Therefore suggestions about possible volcanic vent locations are based on 2D facies variations (Fig. 4). Another caveat is that the effects of tectonic deformation, including faults, have not been specifically considered when positioning these vents.

The Alpha rhyolite in the Western sector is a relatively small lobe-hyaloclastite flow, and its volcanic vent must be somewhere in the Western sector (Fig. 4a).

The Lemoine rhyolite is interpreted to have formed as several lobe-hyaloclastite flows, coming from several volcanic vents. The unit is thickest in the mine area, and there must be a vent or several vents in this general area, although the details of facies variations have not been documented there. The tuffaceous horizon halfway up the unit in the mine area (Mercier-Langevin et al. 2014) may separate two stacked flows. Within the study area, the westward increase in hyaloclastite from DDH LEM34 to DDH LEM-15 (Fig. 4b) suggests that a volcanic vent is located somewhere east of DDH LEM-34.

The origin of the Lemoine dacite is less clear, but the best hypothesis is that it is also a lava flow. Based on thickness variations, the volcanic vent must be located east of the study area (Fig. 2).

The origin of the HwQFP is also more difficult to interpret. Clear lobes exist near Lake Yvette (Fig. 2), so 
the unit must be partly effusive. However, the overall low proportion of hyaloclastite in the HwQFP within the study area is distinctive. It could indicate that this unit partly consists of sills. Alternatively, paleo-seafloor topography could be responsible for the greater abundance in fragmental facies to the WSW of the study area. The abundance of HwQFP feeder dykes in the Western sector (e.g., ESM2, Fig. S2, near $390 \mathrm{~m}$ ) is an argument for a volcanic vent location in this sector.

Mafic to intermediate lavas

Mafic to intermediate lavas often form massive and pillowed flows when emplaced underwater. Such lavas tend to thin with distance from the vent, unless strong topography is involved. There is often a general progression from dominantly massive to more pillows and finally more hyaloclastite with distance from the vent (e.g., Dimroth et al. 1978).

Taking this into account, the main vent(s) for the Lemoine andesite must be in the centre of the study area, between DDHs LEM-49 and LEM 36, where the unit's thickness is the greatest and the proportion of hyaloclastite the smallest (Figs. 2, 4). The decrease in the proportion of hyaloclastite in DDH LEM-44 indicates the possibility of a minor volcanic vent in this area (Fig. 4).

\section{Geological evolution and architecture of the Lemoine Member}

Lower part of the Lemoine Member

The felsic tholeiitic magmatism in the Waconichi Formation has been interpreted as the product of partial melting of a pre-existing tholeiitic basalt (Bédard et al. 2010). No clear trace of the Obatogamau Formation the pre-Waconichi tholeiitic basalt - can be found in the Lemoine area, as the felsic rocks of the Waconichi Formation are directly adjacent to the Lac Doré Complex (LDC). But a mafic ocean floor (grey on Fig. 13a) likely existed before felsic magmatism developed.

The oldest part of the Lemoine Member in the study area is the extrusive portion of the FIIIb Alpha rhyolite, dated at 2728.4 $\pm 0.7 \mathrm{Ma}$ (Fig. 13a). The Alpha rhyolite in the Western sector consists of a small lobehyaloclastite flow, with a local volcanic vent (Fig. 4a). High alteration intensity in DDHs LEM-15 and LEM18 (Figs. 10a, and ESM2, Figs S1a, S2) and the presence of an alteration assemblage (Fig. 11a) similar to one associated with high temperature alteration in the Lemoine deposit area (Mercier-Langevin et al. 2014), indicate that the area was proximal to a hydrothermal upflow zone and may be prospective for VMS mineralization.
The extrusive portion of the Alpha rhyolite is overlain by the FIIIb Lemoine rhyolite, dated at $2727.7 \pm 1.0 \mathrm{Ma}$ (Fig. 13b). It extends laterally for up to $10 \mathrm{~km}$, with the thickest portion in the Lemoine mine area (Fig. 2). The lateral extent of the Lemoine rhyolite coupled with the quantitative analysis of volcanic facies suggest that the unit consists of several lobe-hyaloclastite flows. Volcanic vents are proposed both near the former mine and in the study area, between DDH LEM-34 in the Western sector and DDH LEM-36 in the Raft sector (Fig. 4). Well-developed high-temperature alteration in the area of DDH LEM-36 (Fig. 11a and ESM2, Fig. S1c) also indicates the presence of a paleohydrothermal upflow zone in the Raft sector (Fig. 13b).

The Lemoine dacite represents a thin, yet extensive unit, of possible lava flow origin, located in the Eastern and Raft sectors of the study area (Fig. 2). Lateral thickness variations of the unit imply that the point of origin is located to the east (Fig. 13c). Alteration intensity in the Lemoine dacite is relatively low, as shown by low alteration index values.

The Lemoine andesite is the most laterally extensive extrusive unit of the lower part of the Lemoine Member. It represents the only mafic to intermediate tholeiitic volcanic unit in the study area and consists of massive and pillowed flows, with minor hyaloclastite. Thickness and facies variations point to a volcanic vent located at the center of the study area, somewhere between DDHs LEM-49 and LEM-36 (Figs. 4, 13d). This also coincides with one area of intense alteration displaying the chlorite-sericite assemblage (Fig. 11a) and anomalous $\mathrm{Cu}-\mathrm{Zn}-\mathrm{Au}$ values in DDHs LEM-49 and LEM-50 (Fig. 11b).

The absence of exhalative or finely laminated siliceous sedimentary horizons below the Lemoine andesite in the study area (Fig. 11c) implies that the volcanic units were either emplaced relatively quickly or that these horizons were not preserved. A finely laminated siliceous horizon above the Lemoine andesite indicates a pause in volcanism after the emplacement of the lower part of the Lemoine Member.

Upper part of the Lemoine Member

The HwQFP is a felsic unit mostly interpreted as effusive, and perhaps originating in the Western sector (Fig. 14a). Portions of the HwQFP may be intrusive. The HwQFP is overlain by an exhalative horizon (Fig. 11c) indicating another hiatus in effusive volcanism. The bulk of the upper part of the Lemoine Member is composed of the transitional basalt and minor felsic lenses (Fig. 14b). 
Intrusions

The origin of some units in the Lemoine Member was unclear before this study, but the following units are now recognized as intrusive: a portion of the Alpha rhyolite (Fig. 13b); the Coco Lake QFP (Fig. 14c); the Marelle QFP (Fig. 14d); various gabbroic to dioritic intrusions; the dacitic porphyry; and the Gold Hill tonalite. Approximately 55\% of the lower part of the Lemoine Member is therefore considered to be intrusive.

The Marelle QFP is dated at 2727.5 $\pm 0.6 \mathrm{Ma}$, which is within error of the age obtained for the Lemoine rhyolite $(2727.7 \pm 1.0 \mathrm{Ma})$. Because the Marelle QFP cross-cuts almost all units in the Lemoine Member, this means that the following units were emplaced in quick succession, within a maximum of 1.8 m.y.: the Lemoine rhyolite, the intrusive portion of the Alpha rhyolite, the Lemoine dacite, the Lemoine andesite, the HwQFP, at least a portion of the transitional basalt, the Marelle QFP, and probably the Coco Lake QFP. This shows rapid emplacement of the lower part of the Lemoine Member and that the volcanic hiatuses recorded by exhalite horizons were of relatively short duration.

\section{Implications for VMS exploration in the Lemoine Member}

The Lemoine Member east of the former Lemoine mine is considered highly prospective for VMS exploration because: (1) it contains the same stratigraphic succession as that which hosted the Lemoine deposit, including several FIII rhyolites; (2) it contains evidence for high-temperature hydrothermal alteration of the type commonly associated with VMS deposits; (3) several volcanic vents are thought to occur in the area (newly identified by this study), as well as possible synvolcanic faults (Lafrance and Brisson 2006); (4) $\mathrm{Zn}-\mathrm{Cu}-\mathrm{Au}-\mathrm{Ag}$ metal anomalies occur at various stratigraphic levels; (5) the geology is similar to that of the prolific Matagami district (Debreil et al. 2018). The high abundance of felsic to mafic intrusions within the lower part of the Lemoine Member, and the proximity with the intrusive LDC, means that focused heat flow was likely (Galley 2003). Geochemistry suggests that the extrusive felsic units from the lower part of the Lemoine Member (Fig. 7f) were derived from magmas generated by low-pressure partial melting (Barrett and MacLean 1999; Hart et al. 2004), implying high heat flux in the upper crust. These criteria, and the investigation techniques employed here, in particular the less commonly utilized physical volcanology methods, can also be applied to VMS exploration globally.

\section{Comparison with the Matagami district}

The Chibougamau district bears many similarities in age and geology to the prolific Matagami VMS district (Fig. 1b). Common points are as follows:

- $\quad$ Bimodal-mafic VMS deposits are present in both districts;

- VMS deposits are located close to large synvolcanic mafic layered intrusions $(\sim 2728 \mathrm{Ma}$ LDC in Chibougamau, $2725 \mathrm{Ma}$ Bell River Complex in Matagami; Mortensen 1993; Maier et al. 1996);

- VMS deposits are associated with FIII rhyolites emplaced as lobe-hyaloclastite flows ( 2728$2727 \mathrm{Ma}$ Alpha rhyolite and Lemoine rhyolite in Chibougamau, 2726 Ma Watson Lake rhyolite in Matagami; Ross et al. 2014b; Debreil et al. 2018; this study);

- The hangingwall volcanic sequence is dominantly mafic in both districts.

However, many more VMS deposits have been found so far in the Matagami district. The Lemoine deposit was rich in $\mathrm{Au}$, whereas the Matagami deposits are typically Zn-rich. Mechanisms for Au enrichment at Lemoine were discussed by Mercier-Langevin et al. (2014) and may include a higher Au endowment in the crust or mantle. This is consistent with the several types of gold deposits found in the Chibougamau district. Other explanations for the gold enrichment at Lemoine include a magmatic input to the hydrothermal system, and very effective transport and deposition mechanisms for gold (Mercier-Langevin et al. 2014). Another difference between the Matagami and Chibougamau districts is that the Watson Lake Group at Matagami, which hosts the bulk of the felsic volcanic rocks, is typically considered effusive (Debreil et al. 2018), whereas the lower part of the Lemoine Member has a considerable proportion of felsic intrusive rocks.

\section{Association between some VMS deposits and lobe- hyaloclastite flows}

There is an increasing recognition of the spatial association between some VMS deposits and lobehyaloclastite flows. In the Abitibi Subprovince, examples include Matagami (Debreil et al. 2018), Noranda (Gibson et al. 1999) and Chibougamau (this study). These lobe-hyaloclastite flows are all FIII-type, indicating high eruption temperatures and probably relatively low viscosities (Hart et al. 2004) compared to lava producing blocky domes. FIII rhyolites indicate shallow melting (Hart et al. 2004) and in the three districts mentioned, are associated with high heat flow environments related with large subvolcanic intrusions.

To our knowledge, no detailed documentation of the association between lobe-hyaloclastite flows and VMS 
deposits yet exists outside the Abitibi, but this may be due to a scarcity of detailed volcanological studies in FIII rhyolites elsewhere. In the Iberian Pyrite Belt, near the Rio Tinto mining district, Valenzuela et al. (2011) describe a $60 \mathrm{~m}$-thick, mostly coherent rhyolitic lava that extends laterally over $3 \mathrm{~km}$, and propose that the lava had a low viscosity. No REE analyses are provided, but in the $\mathrm{Zr} / \mathrm{Y}$ versus $\mathrm{Y}$ diagram of Lesher et al. (1986), this lava plots in the joint field for FII and FIIIa rhyolites.

\section{Conclusions}

Volcanic and intrusive units in the Lemoine Member are identified based on a combination of stratigraphic position, texture and immobile element ratios. Based on volcanic facies, we propose a mode of emplacement for each unit that shows that the majority of the felsic rocks in the Lemoine Member is made up of porphyritic, shallow subvolcanic intrusive units. Four of the felsic units are extrusive, and at least two (Alpha rhyolite in the Western sector; Lemoine rhyolite) are interpreted as lobe-hyaloclastite lava flows. Five volcanic vent areas are identified based on a combination of volcanic facies and thickness variations.

Three distinct alteration assemblages have been mapped in the study area, and their pattern is similar to that documented near the Lemoine mine, with hightemperature, chlorite-rich alteration in older volcanic units and lower-temperature, more sericite- and carbonate-rich alteration in younger units. Hydrothermal up-flow zones correspond with inferred synvolcanic faults and contain anomalous $\mathrm{Cu}-\mathrm{Zn}-\mathrm{Ag}$ $\mathrm{Au}$. The abundance of subvolcanic intrusions, including the LDC, suggests that focused heat flow was present. Some of these intrusions, such as the Marelle QFP, have been shown to have the same age as effusive felsic units, confirming their synvolcanic timing.

\section{Acknowledgements}

Funding for this project came from a Collaborative Research and Development Grant from the Natural Sciences and Engineering Research Council of Canada. The industrial partner was Cogitore Resources Inc. (now Yorbeau Resources Inc.). Significant in kind support was offered by the Geological Survey of Canada (Targeted Geoscience Initiative program). Discussions with Tony Brisson, François Leclerc, Francis Lefebvre, Sylvain Lépine, and Gérald Riverin on the geology of the Chibougamau area were very helpful. Michel Houlé and Steve Piercey read the MSc thesis of the second author and made helpful suggestions. Jean-Philippe Pomerleau and Meghan Moher served as field assistants. We thank journal reviewers Steve Hollis and Steve Piercey, associate editor David Huston, and executive editor Georges
Beaudoin, for constructive comments on the manuscript.

\section{References}

Agrawal S, Guevara M, Verma SP (2008) Tectonic discrimination of basic and ultrabasic volcanic rocks through log-transformed ratios of immobile trace elements. Internat Geol Rev 50:1057-1079

Allard GO (1976) The Doré Lake Complex and its importance to Chibougamau geology and metallogeny. Ministère des richesses naturelles, report DP 368, $446 \mathrm{p}$.

Allard G, Gobeil A (1984) General geology of the Chibougamau region. In Guha J, Chown EH (eds) Chibougamau, stratigraphy and mineralization, Canadian Institute of Mining and Metallurgy, Special Volume 34:5-19

Allard GO, Caty JL, Gobeil A (1985) The Archean supracrustal rocks of the Chibougamau area. In Ayres LD, Thurston PC, Card KD, Weber W (eds) Evolution of Archean Supracrustal Sequences. Geological Survey of Canada, Special Paper 28:55-63

Barrett TJ, MacLean WH (1999) Volcanic sequences, lithogeochemistry, and hydrothermal alteration in some bimodal volcanic-associated massive sulfide systems In: Barrie CT, Hannington MD (eds) Volcanic-associated massive sulfide deposits: processes and examples in modern and ancient settings. Society of Economic Geologists, Reviews in Economic Geology 8, pp 101-131.

Barrie CT, Hannington MD (1999) Classification of volcanicassociated massive sulfide deposits based on host rock composition In: Barrie CT, Hannington MD (eds) Volcanic-associated massive sulfide deposits: processes and examples in modern and ancient settings. Society of Economic Geologists, Reviews in Economic Geology 8, pp 1-11.

Bédard JH, Leclerc F, Harris LB, Goulet N (2009) Intra-sill magmatic evolution in the Cummings Complex, Abitibi greenstone belt: Tholeiitic to calc-alkaline magmatism recorded in an Archaean subvolcanic conduit system. Lithos 111:47-71

Bédard JH, Leclerc F, Harris LB., Roy P (2010) Calc-alkaline interuptions of a tholeiitic sequence, Chibougamau, Abitibi belt: remelting of a maturing juvenile oceanic plateau. "Evolving Early Earth", $5^{\text {th }}$ International Archean Symposium, Sept. 5-9 2010, Perth, Australia

Boulerice A (2016) Volcanology of the Lemoine Member of the Waconichi Formation, Abitibi Subprovince, Chibougamau, Quebec. MSc thesis, Institut national de la recherche scientifique, Québec, Canada, 193 p.

Carignan G (2010) Les amas sulfurés à zinc-cuivre archéens du Lac Scott, Chibougamau, Québec. Unpublished MSc thesis, Université du Québec à Montréal, Canada, $103 \mathrm{p}$.

Chown EH, Daigneault R, Mueller W, Mortensen JK (1992) Tectonic evolution of the Northern Volcanic Zone, Abitibi belt, Quebec. Can J Earth Sci 29:2211-2225.

Cote-Mantha O, Daigneault R, Gaboury D, Chartrand F, Pilote P (2012) Geology, alteration, and origin of Archean $\mathrm{Au}-\mathrm{Ag}-\mathrm{Cu}$ mineralization associated with the synvolcanic Chibougamau Pluton: the Brosman 
prospect, Abitibi greenstone belt, Canada. Econ Geol 107:909-934.

Daigneault R, Allard GO (1990) Le Complexe du lac Doré et son environnement géologique. Ministère de l'Énergie, des Mines et des Ressources du Québec, report MM 89-03, $275 \mathrm{p}$.

David J, Davis DW, Dion C, Goutier J, Legault M, Roy P (2007) Datations U-Pb effectuées dans la Sousprovince de l'Abitibi à la suite des travaux de 20052006. Ministère des Ressources naturelles et de la Faune du Québec, report RP-2007-01, 17 p

David J, Vaillancourt D, Bandyayera D, Simard M, Goutier J, Pilote P, Dion C, Barbe P (2011) Datations U-Pb effectuées dans les sous-provinces d'Ashuanipi, de La Grande, d'Opinaca et d'Abitibi en 2008-2009. Ministère des Ressources naturelles et de la Faune du Québec, report RP 2010-11, 37 p.

Debreil J-A, Ross P-S, Mercier-Langevin P (2018) The Matagami district, Abitibi Greenstone Belt, Canada: volcanic controls on Archean volcanogenic massive sulfide deposits associated with voluminous felsic volcanism. Econ Geol 113:891-91

Dimroth E, Cousineau P, Leduc M, Sanschagrin Y (1978) Structure and organisation of Archean subaqueous basalt flows, Rouyn-Noranda area, Quebec, Canada. Can J Earth Sci 15:902-918.

Donahue JC (1982) The geology and petrochemistry of the Patino-Lemoine deposit and its host rocks, Lemoine Township, Quebec. Unpublished MSc thesis, University of Georgia, Athens, 275 p.

Dube B, Guha J (1992) Relationship between northeasttrending regional faults and Archean mesothermal gold-copper mineralization; Cooke Mine, Abitibi greenstone belt, Quebec, Canada. Econ Geol 87:15251540 .

Franklin JM (1997) Lithogeochemical and mineralogical methods for base metal and gold exploration In: Gubins AG (ed) Exploration 97: Fourth Decennial International Conference on Mineral Exploration, pp 191-208.

Franklin JM, Gibson HL, Jonasson IR, Galley AG (2005) Volcanogenic massive sulfide deposits In: Hedenquist JW, Thompson JFH, Goldfarb RJ, Richards JP (eds) Society of Economic Geologists, Economic Geology One Hundredth Anniversary Volume, pp 523-560.

Galley AG (2003) Composite synvolcanic intrusions associated with Precambrian VMS-related hydrothermal systems. Mineral Dep 38:443-473.

Galley AG, Hannington MD, Jonasson IR (2007) Volcanogenic massive sulphide deposits In: Goodfellow WD (ed) Mineral deposits of Canada. Geological Association of Canada, Mineral Deposits Division, Special Publication No. 5, pp 141-161.

Genna D, Gaboury D, Roy G (2014) The Key Tuffite, Matagami Camp, Abitibi Greenstone Belt, Canada: petrogenesis and implications for VMS formation and exploration. Mineral Dep 49:489-512.

Gibson HL, Morton RL, Hudak GJ (1999) Submarine volcanic processes, deposits, and environments favorable for the location of volcanic-associated massive sulfide deposits In: Barrie CT, Hannington MD (eds) Volcanic-associated massive sulfide deposits: processes and examples in modern and ancient settings. Society of Economic Geologists, Reviews in Economic Geology 8, pp 13-51.

Gifkins C, Herrmann W, Large R (2005) Altered volcanic rocks; a guide to description and interpretation. Centre for Ore Deposit Research, University of Tasmania, Hobart, Australia, 275 p.

Guha J, Dube B, Pilote P, Chown EH, Archambault G, Bouchard G (1988) Gold mineralization patterns in relation to the lithologic and tectonic evolution of the Chibougamau mining district, Quebec, Canada. Miner Dep 23:293-298.

Hart TR, Gibson HL, Lesher CM (2004) Trace element geochemistry and petrogenesis of felsic volcanic rocks associated with volcanogenic massive $\mathrm{Cu}-\mathrm{Zn}$ $\mathrm{Pb}$ sulfide deposits. Econ Geol 99:1003-1013.

Hollis SP, Yeats CJ, Wyche S, Barnes SJ, Ivanic TJ, Belford SM, Davidson GJ, Roache AJ, Wingate MTD (2015) A review of volcanic-hosted massive sulfide (VHMS) mineralization in the Archaean Yilgarn Craton, Western Australia: Tectonic, stratigraphic and geochemical associations. Precamb Res 260:113-135.

Ishikawa Y, Sawaguchi T, Iwaya S, Horiuchi M (1976) Delineation of prospecting targets for Kuroko deposits based on modes of volcanism of underlying dacite and alteration halos (in Japanese with English abstract). Mining Geol 26:105-117.

Joanisse A (1998) Géochronologie des minéralisations filoniennes à $\mathrm{Cu}-\mathrm{Au}$ retrouvées dans le complexe du lac Doré. Unpublished MSc thesis, Université du Québec à Montréal, Canada, $51 \mathrm{p}$.

Lafrance B, Brisson T (2006) Rapport sur le programme de forage 2005, projet Lemoine. Mining exploration file submitted by Woodruff Capital Management Inc. to Ministère de l'Énergie et des Ressources naturelles (Québec), GM 62564, 334 p.

Large RR, Gemmell JB, Paulick H, Huston DL (2001) The alteration box plot: a simple approach to understanding the relationship between alteration mineralogy and lithogeochemistry associated with volcanic-hosted massive sulfide deposits. Econ Geol 96:957-971.

Leclerc F, Bédard JH, Harris LB, McNicoll V, Goulet N, Roy P, Houle P (2011) Tholetiic to calc-alcaline cyclic volcanism in the Roy Group, Chibougamau area, Abitibi Greenstone Belt - revised stratigraphy and implications for VHMS exploration. Can J Earth Sci 48:661-694.

Leclerc F, Harris LB, Bedard JH, van Breemen O, Goulet N (2012) Structural and stratigraphic controls on magmatic, volcanogenic, and shear zone-hosted mineralization in the Chapais-Chibougamau mining camp, northeastern Abitibi, Canada. Econ Geol 107:963-989.

Lesher CM, Goodwin AM, Campbell IH, Gorton MP (1986) Trace-element geochemistry of ore-associated and barren, felsic metavolcanic rocks in the Superior Province, Canada. Can J Earth Sci 23:222-237.

MacLean WH, Barrett TJ (1993) Lithogeochemical techniques using immobile elements. J Geochem Explor 48:109-133. 
Maier WD, Barnes S-J, Pellet T (1996) The economic significance of the Bell River Complex, Abitibi subprovince, Quebec. Can J Earth Sci 33:967-980.

Mattinson JM (2005) Zircon U-Pb chemical abrasion ("CATIMS") method: combined annealing and multi-step partial dissolution analysis for improved precision and accuracy of zircon ages. Chem Geol 220:47-66.

Mercier-Langevin P, Hannington M, Dubé B, Bécu V (2011) The gold content of volcanogenic massive sulfide deposits. Mineral Dep 46:509-539.

Mercier-Langevin P, Lafrance B, Bécu V, Dubé B, Kjarsgaard I, Guha J (2014) The Lemoine auriferous volcanogenic massive sulfide deposit, Chibougamau camp, Abitibi greenstone belt, Quebec, Canada: geology and genesis. Econ Geol 109:231-269.

Moisan A (1992) Pétrochimie des grès de la formation de Bordeleau, Chibougamau, Québec. Unpublished MSc thesis, Université du Québec à Chicoutimi, Canada, $121 \mathrm{p}$.

Morin R (1994) Géologie et compilation géologique de la région de Chapais. Ministère de l'Énergie et des Ressources, Québec, report MM 91-02, 56 p.

Mortensen JK (1993) U - Pb geochronology of the eastern Abitibi Subprovince. Part 1: Chibougamau Matagami - Joutel region. Can J Earth Sci 30:11-28.

Nakamura N (1974) Determination of REE, Ba, Fe, Mg, Na and $\mathrm{K}$ in carbonaceous and ordinary chondrites. Geochim Cosmochim Acta 38:757-775

Parrish RR, Roddick JC, Loveridge WD, Sullivan RW (1987) Uranium-lead analytical techniques at the Geochronology Laboratory, Geological Survey of Canada; in Radiogenic age and isotopic studies, Report 1: Geological Survey of Canada Paper 87-2, p. 3-7.

Patel JM, Ogryzlo SP, Didur R (1977) Lemoine mine discovered and developed on a small budget. Can Mining J, April 1977:33-34.

Piercey SJ, Chaloux EC, Peloquin AS, Hamilton MA, Creaser RA (2008) Synvolcanic and younger plutonic rocks from the Blake River Group: implications for regional metallogenesis. Econ Geol 103:1243-1268.

Pilote P (1998) Géologie et métallogénie du district minier de Chapais-Chibougamau. Ministère de lećnergie et des Ressources, Québec, report DV-98-03, 187 p.

Riverin G (2003) Rapport sur le programme de forage 2002, projet Lemoine. Mining exploration file submitted by Les Mines Inmet to Ministère de l'Énergie et des Ressources naturelles (Québec), GM 60029, 286 p.

Roberts RG (1975) The geological setting of the Mattagami Lake Mine, Quebec; a volcanogenic massive sulfide deposit. Econ Geol 70:115-129.

Roddick JC (1987) Generalized numerical error analysis with applications to geochronology and thermodynamics. Geochim Cosmochim Acta 51:2129-2135.

Rogers R, Ross P-S, Goutier J, Mercier-Langevin P (2014) Using physical volcanology, chemical stratigraphy, and pyrite geochemistry for volcanogenic massive sulfide exploration: an example from the Blake River Group, Abitibi Greenstone Belt. Econ Geol 109:61-88
Roscoe WE, Masun KM (2017) Technical report on the mineral resource estimate for the Scott Lake project, northwestern Québec, Canada. 43-101 report prepared by Roscoe Postle Associates Inc. for Yorbeau Resources Inc., 124 p., downloaded from http://www.yorbeauresources.com on June $1^{\text {st }}, 2018$.

Ross P-S, Bédard JH (2009) Magmatic affinity of modern and ancient subalkaline volcanic rocks determined from trace-element discriminant diagrams. Can J Earth Sci 46:823-839

Ross P-S, Mercier-Langevin P (2014) The volcanic setting of VMS and SMS deposits: a review. Geoscience Canada 41:365-377.

Ross P-S, Bourke A, Leclerc F, Boulerice AR (2014a) Analyse multiparamétrique à haute résolution de carottes de forage dans la région de Chibougamau 2012-2014, rapport final. Ministère des Ressources naturelles du Québec, report MB 2014-05, 128 p.

Ross P-S, McNicoll VJ, Debreil JA, Carr P (2014b) Precise $\mathrm{U}-\mathrm{Pb}$ geochronology of the Matagami mining camp, Abitibi Greenstone Belt, Quebec: stratigraphic constraints and implications for volcanogenic massive sulfide exploration. Econ Geol 109:89-101

Ross P-S, Bourke A, Mercier-Langevin P, Lépine S, Leclerc F, Boulerice A (2016) High-resolution physical properties, geochemistry and alteration mineralogy for the host rocks of the Archean Lemoine auriferous VMS deposit, Canada. Econ Geol 111:561-1574

Salmon B (2010) Technical report on the mineral resource estimate of the Scott Lake project, northern Québec, for Cogitore Resources Inc. Scott Wilson Roscoe Postle Associates Inc. NI 43-101 report, project 1430,199 p.

Salmon B, McDonough B (2011) Technical report on the mineral resource estimate of the Scott Lake project, northern Québec, Canada. Roscoe Postle Associates Inc. NI 43-101 report, project 1734, $144 \mathrm{p}$.

Saunders JA, Allard GO (1990) The Scott Lake deposit: a contact-metamorphosed volcanogenic massive sulfide deposit, Chibougamau area, Quebec. Can J Earth Sci 27:180-186.

Sun S-S, McDonough WF (1989) Chemical and isotopic systematics of oceanic basalts: implications for mantle composition and processes. In: Saunders AD, Norry MJ (eds) Magmatism in the ocean basins. Geological Society of London, Special Publication 42, pp 313-345.

Valenzuela A, Donaire T, González-Roldán MJ, Toscano M, Pascual E (2011) Volcanic architecture in the Odiel river area and the volcanic environment in the Riotinto-Nerva Unit, Iberian Pyrite Belt, Spain. J Volcanol Geotherm Res 202:29-46.

Winchester JA, Floyd PA (1977) Geochemical discrimination of different magma series and their differentiation products using immobile elements. Chem Geol 20:325-343

York D (1969) Least squares fitting of a straight line with correlated errors: Earth Planet Sci Lett 5:320-324 
Table 1. Lithofacies characteristics for the Lemoine Member.

\begin{tabular}{|c|c|c|c|}
\hline Stratigraphic unit & $\begin{array}{l}\text { Thickness in study } \\
\text { area }\end{array}$ & Lithofacies in study area & Texture and petrography of coherent rocks \\
\hline \multicolumn{4}{|l|}{ Intrusive units } \\
\hline Gold Hill tonalite & Discordant & Always coherent & $\begin{array}{l}\text { Phaneritic (Fig. } 6 \mathrm{~h} \text { ) } \\
70 \% \text { 2-4 mm plag, } 10-20 \% 3-4 \mathrm{~mm} \text { qtz, minor K-feldspar } \\
10-20 \% \text { pink to dark grey aphanitic groundmass }\end{array}$ \\
\hline Dacitic porphyry & $0-80 \mathrm{~m}$ in total & Always coherent (multiple subvolcanic sills) & $\begin{array}{l}1-2 \% 1-3 \mathrm{~mm} \text { round qtz phenocr. } \\
10-20 \% 1-4 \mathrm{~mm} \text { subhedr. plag phenocr. }\end{array}$ \\
\hline Marelle QFP & $165-660 \mathrm{~m}$ in total & Always coherent (multiple subvolcanic sills) & $\begin{array}{l}\text { 10-25\% 4-7 mm, euhedr., locally zoned, resorbed blue qtz phenocr. (Fig. 6g) } \\
\text { 10-20\% 3-5 mm subhedr. to euhedr. micropoikilitic plag. phenocr. } \\
\text { Aphanitic groundmass }\end{array}$ \\
\hline Coco Lake QFP & $0-140 \mathrm{~m}$ in total & Always coherent (multiple subvolcanic sills) & $\begin{array}{l}\text { 7-15\% 2-4 mm blue qtz phenocr. (Fig. } 6 \mathrm{f} \text { ) } \\
1-5 \% 2-5 \mathrm{~mm} \text { plag phenocr. }\end{array}$ \\
\hline $\begin{array}{l}\text { Alpha rhyolite in Raft } \\
\text { sector }\end{array}$ & $0-115 \mathrm{~m}$ in total & $\begin{array}{l}\text { Always coherent (multiple subvolcanic sills) } \\
\text { Contains enclaves of Lemoine rhyolite, near } \\
\text { contact (Fig. 6e) }\end{array}$ & $\begin{array}{l}\text { Trace-5\%, 1-3 mm qtz phenocr. } \\
\text { Coarse "leopard-like" spherulitic texture (Fig. 6e); spherules average 2-4 mm, } \\
\text { locally } \leq 1 \mathrm{~cm} \text { (larger spherules commonly coalesce) }\end{array}$ \\
\hline \multicolumn{4}{|c|}{ Extrusive units, upper part of Lemoine Member } \\
\hline Transitional basalt & $>300 \mathrm{~m}$ & $\begin{array}{l}\text { Massive \& pillowed flows } \\
\text { Thin hyaloclastite bands }\end{array}$ & $\begin{array}{l}\text { Mostly aphyric and aphanitic (Fig. 6d) } \\
\text { Locally amygdaloidal (3-6\%, qtz-carbonate) }\end{array}$ \\
\hline HwQFP & $0-120 \mathrm{~m}$ & $\begin{array}{l}\text { Overwhelmingly massive } \\
\text { One DDH has hyaloclastite }\end{array}$ & $\begin{array}{l}\text { 3-7\% 1-4 mm qtz phenocr. (Fig. 6a) } \\
\text { 5-8\% 1-4 mm fp phenocr. } \\
\text { Local large Fe-carbonate amygdales (Fig. 6b) } \\
\text { Local epidote patches }\end{array}$ \\
\hline \multicolumn{4}{|c|}{ Extrusive units, lower part of Lemoine member } \\
\hline Lemoine andesite & $\leq 180 \mathrm{~m}$ & $\begin{array}{l}\text { Massive > pillows }(15-80 \mathrm{~cm} \text { across, Fig. } 5 \mathrm{~g}) \\
0-30 \% \text { hyaloclastite }\end{array}$ & $\begin{array}{l}\text { Mostly aphyric \& aphanitic } \\
\text { Local pyroxene phenocr., local plag phenocr. } \\
\text { Locally amygdaloidal (1-5\%, 1-3 mm, blue qtz) (Fig. } 5 \mathrm{~h})\end{array}$ \\
\hline Lemoine dacite & $0-60 \mathrm{~m}$ & $\begin{array}{l}\text { Mostly massive } \\
10-45 \% \text { hyaloclastite }\end{array}$ & $\begin{array}{l}\text { Trace- } 1 \% 1 \mathrm{~mm} \text { blue qtz phenocr. } \\
\text { Trace } 1 \mathrm{~mm} \text { fp phenocr. } \\
\text { Spherulitic }\end{array}$ \\
\hline Lemoine rhyolite & $0-200 \mathrm{~m}$ & $\begin{array}{l}\text { Mostly massive (local polygonal joints, Fig. 5c) \& } \\
\text { lobate (Figs. } 5 \text { d, 5e) } \\
<5-30 \% \text { hyaloclastite (Fig. } 5 \text { f) }\end{array}$ & $\begin{array}{l}1-5 \%, 1-3 \mathrm{~mm} \text { euhedr. blue qtz phenocr. surrounded by milky qtz corona (also } \\
\text { containing chl+ser) } \\
\text { Aphanitic groundmass }\end{array}$ \\
\hline $\begin{array}{l}\text { Alpha rhyolite in } \\
\text { Western sector }\end{array}$ & $0-120 \mathrm{~m}$ & $\begin{array}{l}\text { Mostly massive (Fig. } 5 \text { a) \& lobate } \\
<5 \% \text { hyaloclastite (Fig. } 5 \text { b) }\end{array}$ & $\begin{array}{l}\text { 3-7\% (locally } 15 \% \text { ), } 1-3 \mathrm{~mm} \text { resorbed blue qtz phenocr. (Fig. 5a) } \\
0-3 \% 1-3 \mathrm{~mm} \text { fp phenocr. } \\
\text { Aphanitic groundmass }\end{array}$ \\
\hline
\end{tabular}

Abbreviations: $\mathrm{chl}=$ chlorite, $\mathrm{fp}=$ felsdspar, plag $=$ plagioclase, ser $=$ sericite, qtz $=$ quartz 
Table 2. Geochemical summary of the Lemoine Member (average concentrations and ratios)*.

\begin{tabular}{|c|c|c|c|c|c|c|c|c|c|c|c|c|c|c|c|c|}
\hline & $\mathbf{n}$ & $\mathrm{SiO}_{2}$ & $\mathrm{TiO}_{2}$ & $\mathrm{Fe}_{2} \mathrm{O}_{3}{ }^{\mathrm{T}}$ & $\mathbf{Z r}$ & $\mathbf{V}$ & $\mathbf{T i} / \mathbf{Z r}$ & $\mathbf{A l} / \mathbf{Z r}$ & $\mathbf{Z r} / \mathbf{Y}$ & $\mathbf{T h} / \mathbf{Y b}$ & La/Lu & La/Sm & Gd/Lu & Composition & Composition & $\begin{array}{c}\text { Magmatic } \\
\text { affinity }\end{array}$ \\
\hline & & $\%$ & $\%$ & $\%$ & ppm & ppm & & & & & c.n. & c.n. & c.n. & W\&F77Fig2 & W\&F77Fig6 & R\&B09Fig7 \\
\hline \multicolumn{17}{|l|}{ Intrusive units } \\
\hline $\begin{array}{l}\text { Gold Hill } \\
\text { tonalite }\end{array}$ & 22 & 62.9 & 0.42 & 3.9 & 140 & n.d. & 18 & 617 & 8.9 & 1.9 & 7.6 & 2.7 & 1.6 & $\begin{array}{l}\text { Andesite to } \\
\text { rhyodacite }\end{array}$ & $\begin{array}{l}\text { Andesite to } \\
\text { rhyodacite }\end{array}$ & CA \\
\hline $\begin{array}{l}\text { Dacitic } \\
\text { porphyry }\end{array}$ & 13 & 63.3 & 0.87 & 9.1 & 331 & n.d. & 17 & 207 & 4.8 & 0.45 & 2.9 & 1.7 & 1.2 & $\begin{array}{l}\text { Andesite to } \\
\text { rhyodacite }\end{array}$ & $\begin{array}{l}\text { Rhyodacite to } \\
\text { dacite }\end{array}$ & TR to CA \\
\hline Marelle QFP & 68 & 71.5 & 0.43 & 4.8 & 367 & n.d. & 7.1 & 178 & 3.4 & 0.49 & 2.9 & 1.8 & 1.2 & $\begin{array}{l}\text { Rhyolite to } \\
\text { rhyodacite }\end{array}$ & $\begin{array}{l}\text { Rhyodacite to } \\
\text { dacite }\end{array}$ & $\mathrm{TR}$ \\
\hline $\begin{array}{l}\text { Coco Lake } \\
\text { QFP }\end{array}$ & 66 & 75.1 & 0.20 & 3.2 & 344 & n.d. & 3.5 & 178 & 2.8 & 0.47 & 2.4 & 1.8 & 1.0 & Mostly rhyolite & Mostly rhyolite & TH to TR \\
\hline \multicolumn{17}{|c|}{ Extrusive units, upper part of Lemoine Member } \\
\hline $\begin{array}{l}\text { Transitional } \\
\text { basalt }\end{array}$ & 221 & 50.6 & 1.3 & 11.8 & 114 & 203 & 69 & 782 & 4.8 & 0.49 & 3.6 & 1.8 & 1.4 & $\begin{array}{l}\text { Andesite to } \\
\text { basalt }\end{array}$ & $\begin{array}{l}\text { Andesite to } \\
\text { basalt }\end{array}$ & $\begin{array}{l}\text { Mostly TR to } \\
\text { CA }\end{array}$ \\
\hline HWQFP & 68 & 70.9 & 0.42 & 5.0 & 476 & n.d. & 5.3 & 137 & 5.3 & 0.50 & 2.7 & 1.9 & 1.1 & $\begin{array}{l}\text { Rhyolite to } \\
\text { com./pan. }\end{array}$ & $\begin{array}{l}\text { Rhyolite to } \\
\text { rhyodacite }\end{array}$ & TR to $\mathrm{CA}$ \\
\hline \multicolumn{17}{|c|}{ Extrusive units, lower part of Lemoine Member } \\
\hline $\begin{array}{l}\text { Lemoine } \\
\text { andesite }\end{array}$ & 81 & 52.4 & 1.9 & 15.1 & 213 & 92 & 54 & 317 & 3.6 & 0.23 & 1.6 & 1.3 & 1.2 & $\begin{array}{l}\text { Andesite to } \\
\text { basalt }\end{array}$ & $\begin{array}{l}\text { Andesite to } \\
\text { basalt }\end{array}$ & TH to TR \\
\hline $\begin{array}{l}\text { Lemoine } \\
\text { dacite }\end{array}$ & 17 & 69.1 & 0.57 & 7.4 & 627 & n.d. & 5.5 & 94 & 4.4 & 0.27 & 1.6 & 1.3 & 1.0 & $\begin{array}{l}\text { Rhyolite to } \\
\text { com./pan. }\end{array}$ & Rhyodacite & TR \\
\hline $\begin{array}{l}\text { Lemoine } \\
\text { rhyolite }\end{array}$ & 119 & 74.2 & 0.19 & 4.6 & 482 & n.d. & 2.3 & 122 & 2.8 & 0.36 & 1.8 & 1.5 & 1.0 & $\begin{array}{l}\text { Rhyolite to } \\
\text { com./pan. }\end{array}$ & Rhyolite & Mostly TH \\
\hline $\begin{array}{l}\text { Alpha } \\
\text { rhyolite }\end{array}$ & 40 & 70.5 & 0.42 & 8.0 & 578 & n.d. & 4.4 & 98 & 4.2 & 0.26 & 1.5 & 1.3 & 1.0 & $\begin{array}{l}\text { Rhyolite to } \\
\text { com./pan. }\end{array}$ & $\begin{array}{l}\text { Rhyolite to } \\
\text { rhyodacite }\end{array}$ & Mostly TR \\
\hline
\end{tabular}

Abbreviations: $\mathrm{CA}=$ calc-alkaline; c.n. = chondrite normalized $($ McDonough $\&$ Sun, 1995); com./pan. $=$ comendite/pantellerite; $\mathrm{n}=$ number of analyses; $\mathrm{n} . \mathrm{d} .=$ no data; R\&B09Fig7 = figure 7 in Ross and Bedard (2009); TH = tholeiitic; TR = transitional; W\&F77Fig2 = figure 2 in Winchester and Floyd (1977).

* Data sources: Actlabs data (ESM1) and Cogitore analyses for $\mathrm{SiO}_{2}$ to $\mathrm{Zr} / \mathrm{Y}$ (except V); Actlabs only for $\mathrm{V}$ and $\mathrm{Th} / \mathrm{Yb}$ to $\mathrm{Gd} / \mathrm{Lu}$. 


\section{Table 3: U-Pb Zircon ID-TIMS analytical data}

\begin{tabular}{|c|c|c|c|c|c|c|c|c|c|c|c|c|c|c|c|c|c|c|c|c|c|}
\hline \multirow[b]{2}{*}{ Fraction $^{1}$} & \multirow[b]{2}{*}{ Description $^{2}$} & \multirow[b]{2}{*}{$\begin{array}{l}\text { Wt. } \\
\text { ug }\end{array}$} & \multirow[b]{2}{*}{$\begin{array}{c}\mathrm{U} \\
\mathrm{ppm}\end{array}$} & \multirow[b]{2}{*}{$\begin{array}{l}\mathrm{Pb}^{3} \\
\mathrm{ppm}\end{array}$} & \multirow[b]{2}{*}{$\frac{206 \mathrm{~Pb}^{4}}{204 \mathrm{~Pb}}$} & \multirow[b]{2}{*}{$\begin{array}{l}\mathrm{Pb}^{5} \\
\mathrm{pg}\end{array}$} & & \multicolumn{6}{|c|}{ Ages (Ma) } & \multirow[b]{2}{*}{$\begin{array}{c}\% \\
\text { Disc }\end{array}$} \\
\hline & & & & & & & $\frac{208 \mathrm{~Pb}}{206 \mathrm{~Pb}}$ & $\frac{207 \mathrm{~Pb}}{235 \mathrm{U}}$ & $\begin{array}{c} \pm 1 S E \\
\text { Abs }\end{array}$ & $\frac{206 \mathrm{~Pb}}{238 \mathrm{U}}$ & $\begin{array}{l} \pm 1 S E \\
\text { Abs }\end{array}$ & $\begin{array}{l}\text { Corr. }^{7} \\
\text { Coeff. }\end{array}$ & $\frac{207 \mathrm{~Pb}}{206 \mathrm{~Pb}}$ & $\begin{array}{c} \pm 1 S E \\
\text { Abs }\end{array}$ & $\frac{206 \mathrm{~Pb}}{238 \mathrm{U}}$ & $\pm 2 \mathrm{SE}$ & $\frac{207 \mathrm{~Pb}}{235 \mathrm{U}}$ & $\pm 2 \mathrm{SE}$ & $\frac{207 \mathrm{~Pb}}{206 \mathrm{~Pb}}$ & $\pm 2 \mathrm{SE}$ & \\
\hline \multicolumn{22}{|c|}{ Alpha rhyolite in LEM-18 (Z11084) } \\
\hline A20-1 $(1 ; C A)$ & $\mathrm{Co}, \mathrm{Clr}$,Eu El,In,Fr,CA2O & 9.7 & 27 & 16 & 3623 & 2.3 & 0.2 & 13.50795 & 0.01655 & 0.51986 & 0.00052 & 0.931 & 18845 & 0.00009 & 2698.6 & 4.4 & 2715.8 & 2.3 & 2728.7 & 1.5 & \\
\hline $20-2(1 ; \mathrm{CA})$ & $\mathrm{Co}, \mathrm{Clr}, \mathrm{Eu} \mathrm{El}, \mathrm{In}, \mathrm{Fr}, \mathrm{CA} 20$ & 4.8 & 19 & 12 & 632 & 4.8 & 0.19 & 13.67247 & 0.02954 & 0.52646 & 0.00114 & 0.884 & 18835 & 0.00020 & 2727.3 & 4.1 & 2726.5 & 9.6 & 2727.8 & 3.4 & 0.1 \\
\hline $0-4($ & $\mathrm{Co}, \mathrm{Clr}, \mathrm{Eu} \mathrm{Pr}, \mathrm{fln}, \mathrm{rFr}, \mathrm{CA} 20$ & 3.6 & 25 & 16 & 1244 & 2.4 & 0.2 & 13.69784 & 0.01917 & 0.52698 & 0.00059 & 0.899 & 0.18852 & 0.00012 & 2728.7 & 5.0 & 2729.0 & 2.6 & 729.3 & 2.1 & 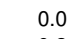 \\
\hline & $\mathrm{Co}, \mathrm{Clr}, \mathrm{E}$ & 3.5 & 27 & 17 & 4483 & 0.7 & 0.2 & 13.70978 & 0.01867 & & 0.00062 & 0.929 & & & & 2.6 & & & & 1.7 & \\
\hline $0-8($ & $\mathrm{Co}, \mathrm{Clr}, \mathrm{Eu}$ & 4.0 & 34 & 21 & 7987 & 0.6 & 0.19 & 13.59505 & 0.01626 & 52374 & 0.00051 & 0.930 & 26 & .00009 & 2721.9 & 2.3 & 2715.0 & 4.3 & 727.0 & 1.5 & 0.5 \\
\hline A) & $\mathrm{Co}, \mathrm{Clr}$, & 6 & 18 & 11 & 2409 & 1.4 & 0.2 & 13.63923 & .01822 & 0.52494 & 0.00061 & 0.913 & 0.18844 & 0.00010 & 2725.0 & 2.5 & 2720.1 & 5.1 & 2728.6 & 1.8 & 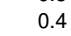 \\
\hline A20-11 (1;CA) & $\mathrm{Co}, \mathrm{Clr}, \mathrm{Eu} \mathrm{Pr}, \mathrm{fln}, \mathrm{rFr}, \mathrm{CA} 20$ & 3. & 24 & 15 & 1265 & 2.1 & 2 & 13.67099 & 0.01957 & 0.52599 & 0.00063 & 0.885 & 0.18850 & 00013 & 2727.2 & 2.7 & 2724.6 & 5.3 & 729.1 & 2.2 & 02 \\
\hline \multicolumn{22}{|c|}{ Lemoine rhyolite in LEM-40 (Z10760) } \\
\hline A10-1 $(1 ; C A)$ & $\mathrm{Co}, \mathrm{Clr}, \mathrm{Eu}$ tip,fln, $\mathrm{CA} 10$ & 6 & 67 & 42 & 1011 & 1.3 & 0.2 & & 50 & $0.0<100$ & & 0.908 & & & & 8.2 & & 3.6 & 7.9 & 2.7 & -0.2 \\
\hline & $\mathrm{Co}$ & 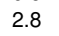 & 45 & 28 & 3008 & 1.4 & 2 & & & & & & & & & 77 & 2727.1 & & & 1.6 & \\
\hline & $\mathrm{Co}, \mathrm{Clr}$ & 1. & 37 & 23 & 682 & 1.8 & 0.2 & 13.7 & 2805 & 2909 & 99 & 0.886 & & & 2727.6 & 3.1 & 7.6 & 8.4 & .9 & 3.9 & -0.5 \\
\hline 1) & $\mathrm{Co}, \mathrm{Clr}$, & 12 & 55 & 34 & 695 & 1.1 & & & 60 & & & 0.890 & & & & 10.1 & & 4.2 & 8 & 3.5 & 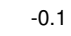 \\
\hline & & 0 & 6 & 39 & 666 & 1.9 & & & & & & 0.874 & & & & 8.2 & & 9 & & 3.3 & -01 \\
\hline A16-6 $(1 ; \mathrm{CA})$ & $\mathrm{Co}, \mathrm{Clr}, \mathrm{Eu} \mathrm{Pr}, \mathrm{fln}, \mathrm{Fr}, \mathrm{CA} 16$ & 1.2 & 58 & 36 & 1972 & 0.8 & 0.2 & 13.62622 & 0.01875 & 0.52459 & 0.00062 & 0.925 & 0.18839 & 0.00010 & 2718.6 & 5.3 & 2724.1 & 2.6 & 2728.1 & 1.8 & \\
\hline \multicolumn{22}{|c|}{ Marelle QFP (Z10988) } \\
\hline $\mathrm{A} 16-1(1 ; \mathrm{CA})$ & $\mathrm{Co}, \mathrm{Clr}, \mathrm{Eu} \mathrm{Pr}, \mathrm{Fr}$ & 5.5 & 31 & 19 & 2090 & 2.7 & 2 & & & & & 0.899 & & & 2725.2 & 4.9 & 2726.5 & 2.5 & 7.5 & 1.9 & 0. \\
\hline & $\mathrm{Co}, \mathrm{Clr}$ & 4.6 & -5 & 2 & 4695 & 1.3 & & & & & & & & & & 4.8 & & 2.4 & & 1.7 & \\
\hline A16-3 & $\mathrm{Co}, \mathrm{Clr}$,Eu & 3. & 41 & 25 & 2663 & 1.6 & 0.2 & 13.65 & 0.01814 & 0.52740 & 0.00 & 0.919 & 0.18830 & & 2730.5 & 5.0 & 2728.7 & 2.5 & 727.3 & 1.7 & \\
\hline & & 9. & 5 & 31 & 10384 & 1.5 & & & & & & & & & & 4.0 & 2727.7 & & & 1.4 & \\
\hline & & 6. & 42 & 2 & 5753 & 1.6 & & & & & & & & & & 4.1 & 2728.6 & 2.2 & 2727.6 & 1.4 & \\
\hline A20-3 $(1 ; \mathrm{CA})$ & $\mathrm{Co}, \mathrm{Clr}$, Eu $\mathrm{Pr}, \mathrm{Fr}, \mathrm{In}, \mathrm{CA} 20$ & 7.7 & 39 & 24 & 5635 & 1.8 & 0.2 & 13.67533 & 0.01635 & 0.52658 & 0.00050 & 0.944 & 0.18835 & 0.00008 & 2727.0 & 4.3 & 2727.5 & 2.3 & 2727.8 & 1.4 & 0.0 \\
\hline
\end{tabular}

Notes:

Number in bracket refers to the number of zircon grains in the analysis. $\mathrm{CA}=$ chemically abraded; $\mathrm{PA}=$ physically abraded.

${ }^{2}$ Fraction descriptions: $\mathrm{Co}=$ Colourless, $\mathrm{Cl}=\mathrm{C}=\mathrm{Clear}$, Eu=Euhedral, $\mathrm{Pr}=\mathrm{Prismatic}, \mathrm{St}=\mathrm{Stubby}$ Prism, El=Elongate, Tip=Tip, $\mathrm{rFr}=\mathrm{Rare}$ Fractures, $\mathrm{fFr}=\mathrm{Few}$ Fractures, $\mathrm{Fr}=\mathrm{Fractures}$, rln=Rare Inclusions, fln=Few Inclusions, In=Inclusions, $\mathrm{CA} 10=$ Chemically

${ }^{4}$ Measured ratio, corrected for spike and fractionation

${ }^{5}$ Total common $\mathrm{Pb}$ in analysis corrected for fractionation and spike

${ }^{6} \mathrm{C}$ orrected for blank $\mathrm{Pb}$ and $\mathrm{U}$ and common $\mathrm{Pb}$, errors quoted are 1 sigma absolute; procedural blank values for this study ranged from $<0.1-0.1 \mathrm{pg}$ for $\mathrm{U}$ and $0.5-2 \mathrm{pg}$ for $\mathrm{Pb}$; $\mathrm{Pb}$ blank isotopic composition is based on the analysis of procedural blanks; corrections for common Pb were made using Stacey and Kramers (1975) compositions 'Correlation Coefficient

${ }^{8}$ Corrected for blank and common $\mathrm{Pb}$, errors quoted are 2 sigma in $\mathrm{Ma}$ 


\section{Figures}

Fig. 1. (a) Location of the Abitibi Subprovince in eastern Canada. (b) Simplified geology of the Abitibi Subprovince showing the location of the Chibougamau district. (c) Simplified geology of the Chibougamau district (modified from Leclerc et al. 2012) showing the location of the Scott Lake and Lemoine VMS deposits, in felsic rocks of the Waconichi Formation.

Fig. 2. Geology of the area around the Lemoine Mine and to the NE. The trace of section A-A' shown in Fig. 3 is marked. Map modified from Lafrance and Brisson (2006), Mercier-Langevin et al. (2014) and Boulerice (2016); U$\mathrm{Pb}$ ages from Mortensen (1993) and this study.

Fig. 3. Cross-section A-A' through the Western sector of study area (see Fig. 2 for location). The section shows the steep dips of the volcanic strata, the stratigraphic order of the units, and their thicknesses.

Fig. 4. Maps of facies variations within volcanic units: (a) Alpha rhyolite, (b) Lemoine rhyolite, (c) Lemoine andesite, (d) HwQFP.

Fig. 5. Photos and detailed map illustrating extrusive facies from the lower part of the Lemoine Member. (a) Alpha rhyolite in the Western sector, coherent facies, with quartz-phyric texture, in DDH LEM-18, near $71.5 \mathrm{~m} \mathrm{depth}$. Ruler shows cm and mm graduations. (b) Alpha rhyolite, lobate facies with spherulites (upper two rows) and hyaloclastite facies (lower row) in DDH LEM-36, $180 \mathrm{~m}$ depth. (c) Lemoine rhyolite on outcrop 13-ARB-13 (see Fig. 2 for location), coherent facies, with polygonal joints. (d) Lemoine rhyolite on outcrop 13-ARB-18, showing lobe surrounded by hyaloclastite. Notebook is $18 \mathrm{~cm}$ long. (e) Map of Lemoine rhyolite on outcrop 13-ARB-18. (f) Lemoine rhyolite on outcrop 13-ARB-01, hyaloclastite facies. (g) Lemoine andesite, pillowed facies, DDH LEM-36, $425 \mathrm{~m}$ depth. (h) Lemoine andesite, with epidote patches (EP) and quartz-pyrrhotite-chlorite-epidote amygdales (Amyg), DDH LEM-52, $454 \mathrm{~m}$ depth.

Fig. 6. Photographs illustrating extrusive facies from the upper part of the Lemoine Member, and intrusive units. (a) HWQFP showing lapilli-sized fragment and porphyritic texture, DDH LEM-52, near $289 \mathrm{~m}$ depth. (b) HwQFP on outcrop 13-ARB-03, showing large iron carbonate amygdales. (c) Lobe in HwQFP near Lake Yvette. (d) Transitional basalt, foliated, with quartz-carbonate veinlets, DDH LEM-44, $165 \mathrm{~m}$ depth. (e) Alpha rhyolite in the Raft sector, outcrop 13-ARB-28. Note the spherulitic texture and the enclave of Lemoine rhyolite. (f) Coco Lake QFP with blue quartz and white feldspar phenocrysts, DDH LEM-31E, $1142.03 \mathrm{~m}$ depth. (g) Marelle QFP, from the $\mathrm{U}-\mathrm{Pb}$ geochronology outcrop near Lake Yvette. (h) Gold Hill tonalite, DDH LEM-52, $542.6 \mathrm{~m}$ depth. All cores shown are BQ size $(3.7 \mathrm{~cm}$ diameter $)$.

Fig. 7. Geochemistry of the Lemoine member. (a)-(b) Classification diagrams from Winchester and Floyd (1977). $\mathrm{AB}=$ alkali basalt. (c) Magmatic affinity diagram from Ross and Bedard (2009). (d) Ti/Zr versus Al/Zr diagram useful for separating the felsic units. (e) Tectonic discrimination diagram for mafic rocks, from Agrawal et al. (2008). $\mathrm{MORB}=$ mid-ocean ridge basalt, $\mathrm{IAB}=$ island arc basalt, $\mathrm{CRB}=$ continental rift basalt, OIB = ocean island basalt. The two axes, DF1 and DF2, are linear combinations of the elements La, Nb, Sm, Th, and Yb. (f) Rhyolite "fertility" diagram from Hart et al. (2004). The subscript 'cn' denotes normalization to the average chondrite of Nakamura (1974). Data sources: our Activation Laboratories data in (a) to (f), and company data in (a)-(d).

Fig. 8. Extended trace element diagrams for volcanic and intrusive units of the Lemoine member. Only the Activation Laboratories data were used here. Primitive mantle normalization values from Sun and McDonough (1989).

Fig. 9. Concordia plots for the three dated samples: (a) Alpha rhyolite; (b) Lemoine rhyolite; (c) Marelle QFP.

Fig. 10. Alteration box plot from Large et al. (2001). (a) Alpha rhyolite in the Western sector and Lemoine rhyolite. (b) All other extrusive and intrusive units in the Lemoine Member, including Alpha rhyolite in the Raft sector. Least altered boxes are from Gifkins et al. (2005) for modern volcanic arcs and Rogers et al. (2014) for modern mid-ocean ridge basalts. Data sources: our Activation Laboratories data, plus Cogitore data. 
Fig. 11. Maps of (a) hydrothermal alteration assemblages, (b) metal anomalies, and (c) exhalative horizons (Fig. 2 for geology legend). Alteration assemblages were drawn from a combination of drill core observations, petrography and geochemistry. Assay samples in drill holes were projected vertically to the surface, but exhalites are shown at the correct stratigraphic position. (d) Photo of exhalative horizon above the HwQFP in DDH LEM-52, $279.7 \mathrm{~m}$.

Fig. 12. Photomicrographs of alteration assemblages, using plane polarized light (a, c, e) and cross-polarized light (b, d, f). (a)-(b) Chlorite (Chl)-sericite (Ser) alteration in the Alpha rhyolite, Western sector, DDH LEM-15, $177.0 \mathrm{~m}$ depth. $\mathbf{Q z}=$ quartz. (c)-(d) Sericite-chlorite alteration in the Lemoine rhyolite, DDH LEM-18, $360 \mathrm{~m}$ depth. The quartz phenocryst is resorbed but has developed an alteration corona rich in quartz. Minor biotite $(\mathbf{B t})$ is present. (e)-(f) Carbonate (Cb)-sericite-chlorite alteration in the HwQFP, DDH LEM-61, 38.6 m.

Fig. 13. Early volcanic evolution of the lower part of the Lemoine Member. (a) Emplacement of the Alpha rhyolite on the paleoseafloor with an active hydrothermal upflow zone. (b) Effusion of the Lemoine rhyolite through two different volcanic vents. The hydrothermal upflow zone active in (a) is partly active through this stage. The emplacement of the Alpha rhyolite continues in the Raft sector after the Lemoine rhyolite. (c) Emplacement of the Lemoine dacite originating east of the study area. (d) Emplacement of the Lemoine andesite possibly associated with two volcanic vents. Hydrothermal upflow is associated with the area proximal to the volcanic vent in the Western sector. The end of the Lemoine andesite is marked by a hiatus in volcanism represented by a tuffaceous layer (not shown), and the Lemoine VMS deposit probably developed at this stage and perhaps in (c) as well. Although the timeline for the emplacement of the LDC is not well defined, it is interpreted here to have migrated upwards in the crust at the same time as the emplacement of the Lemoine Member units as suggested by the two U-Pb ages on the LDC. Only a small portion of the LDC in contact with the Lemoine Member is shown here. The size of the alteration footprint around the inferred hydrothermal vents has been exaggerated to emphasize this important feature.

Fig. 14. Volcanic evolution of the upper part of the Lemoine Member, and some intrusions. (a) Emplacement of the HwQFP from one vent in the study area and a possible second vent to the west, followed by a hiatus in effusive volcanism. (b) Emplacement of the transitional basalt and intercalated felsic lenses. (c) Intrusion of the Coco Lake QFP that forms sills located at contact boundaries between the HwQFP and the Lemoine andesite as well as the HwQFP and the transitional basalt. The Coco Lake QFP also intrudes the Lemoine rhyolite in the Raft sector. (d) Intrusion of the Marelle QFP forming the raft structure in the Raft sector. Gabbros not shown.

\section{Tables}

Table 1. Lithofacies characteristics for the Lemoine Member.

Table 2. Geochemical summary of the Lemoine Member (average concentrations and ratios).

Table 3. U-Pb zircon ID-TIMS analytical data. 

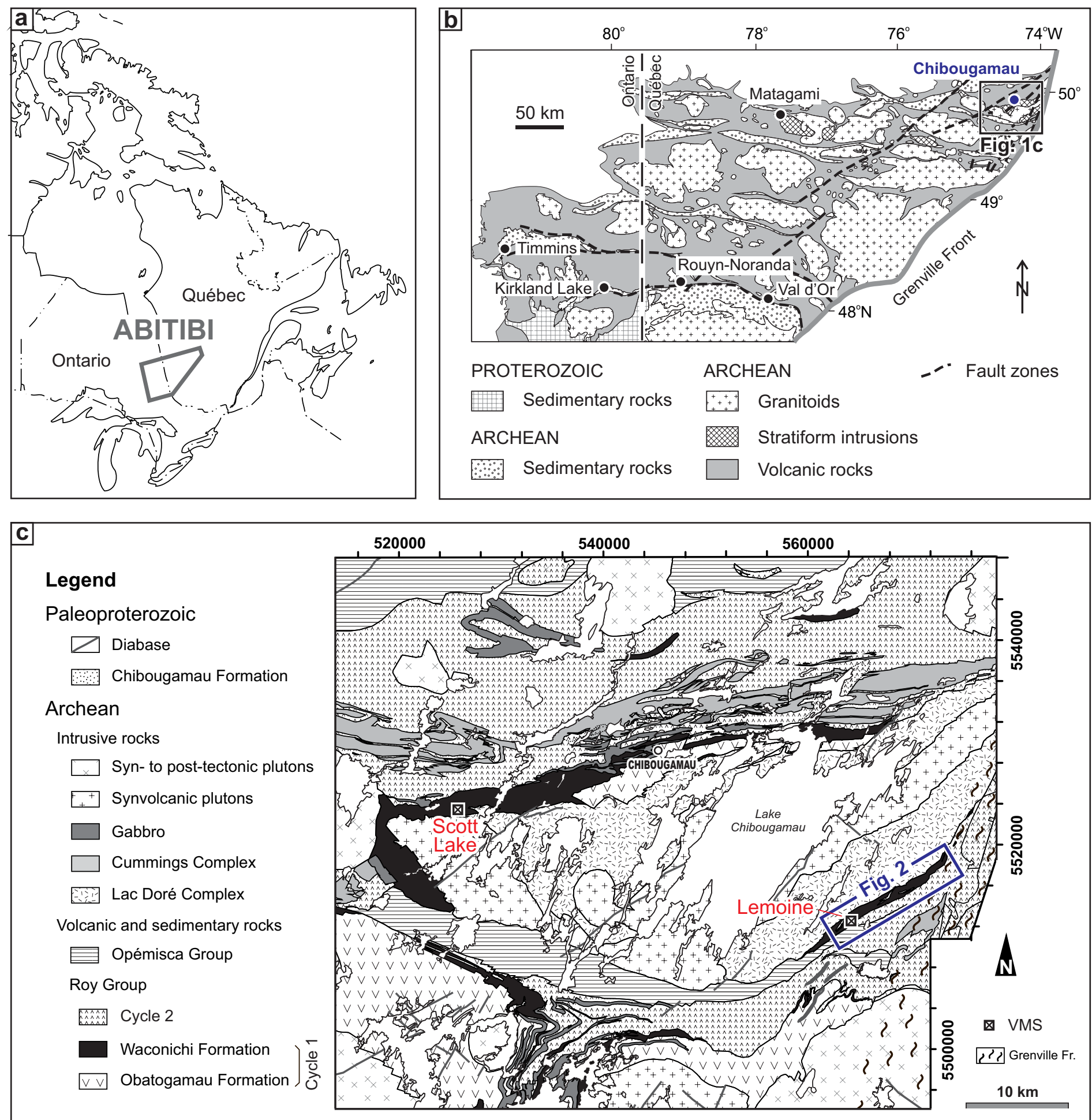


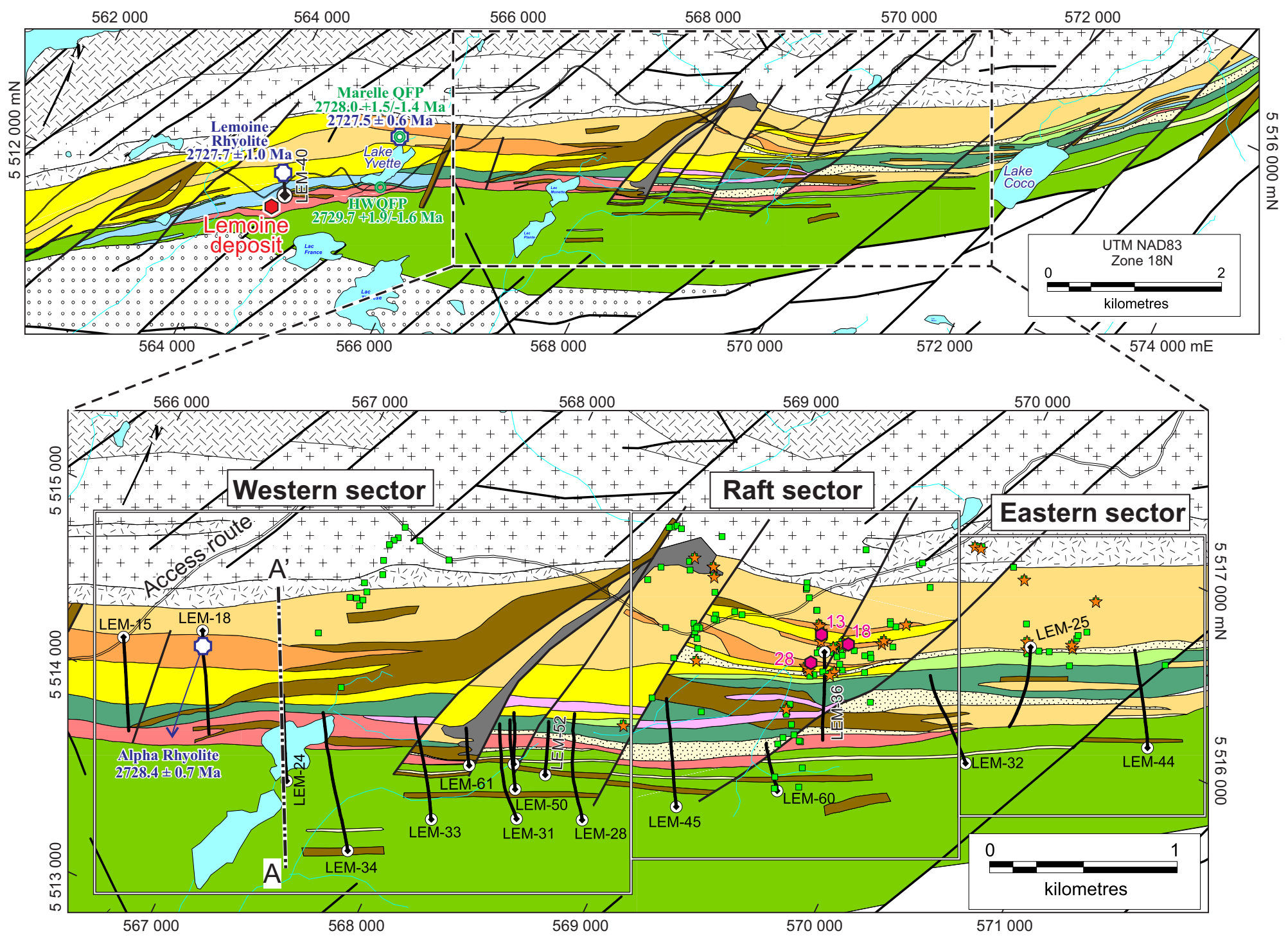

\begin{tabular}{|c|c|c|c|c|}
\hline \multicolumn{3}{|c|}{ Lithology } & \multicolumn{2}{|c|}{ Symbols } \\
\hline \multirow{9}{*}{$\begin{array}{l}\text { Late Intrusions } \\
\begin{array}{l}\square \text { Gold Hill tonalite } \\
\text { Opemisca Group } \\
\text { Wo Stella Formation } \\
\text { Waconichi Formation } \\
\text { Intrusions } \\
\square \text { Lemoine diorite } \\
\square \text { Gabbro } \\
\square \text { Dacitic porphyry } \\
\square \text { Coco Lake QFP } \\
\square \text { Marelle QFP }\end{array}\end{array}$} & Waconichi Formation (cont.) & Lac Doré Complex & $\Theta$ & Drill hole \\
\hline & Upper part of the Lemoine Member & Border zone & $\square$ & Studied outcrops \\
\hline & $\square$ Felsic lenses & $\square$ Granophyre & 28 & $\begin{array}{l}\text { Outcrops mapped in detail } \\
\text { (e. 13-ARB-28) }\end{array}$ \\
\hline & $\square$ Hangingwall QFP & ¿'s Undifferentiated & & Surface samples (aeochemistry) \\
\hline & Lower part of the Lemoine Member & $\begin{array}{l}\text { Other } \\
\square \text { Not mapped }\end{array}$ & 0 & U-Pb sample (new) \\
\hline & $\square$ Lemoine andesite & & (0) & U-Pb sample (Mortensen, 1993) \\
\hline & $\square$ Lemoine dacite & & & Faults \\
\hline & $\square$ Lemoine rhyolite & & & \\
\hline & $\square$ Alpha rhyolite & & & Cross-section \\
\hline
\end{tabular}


A

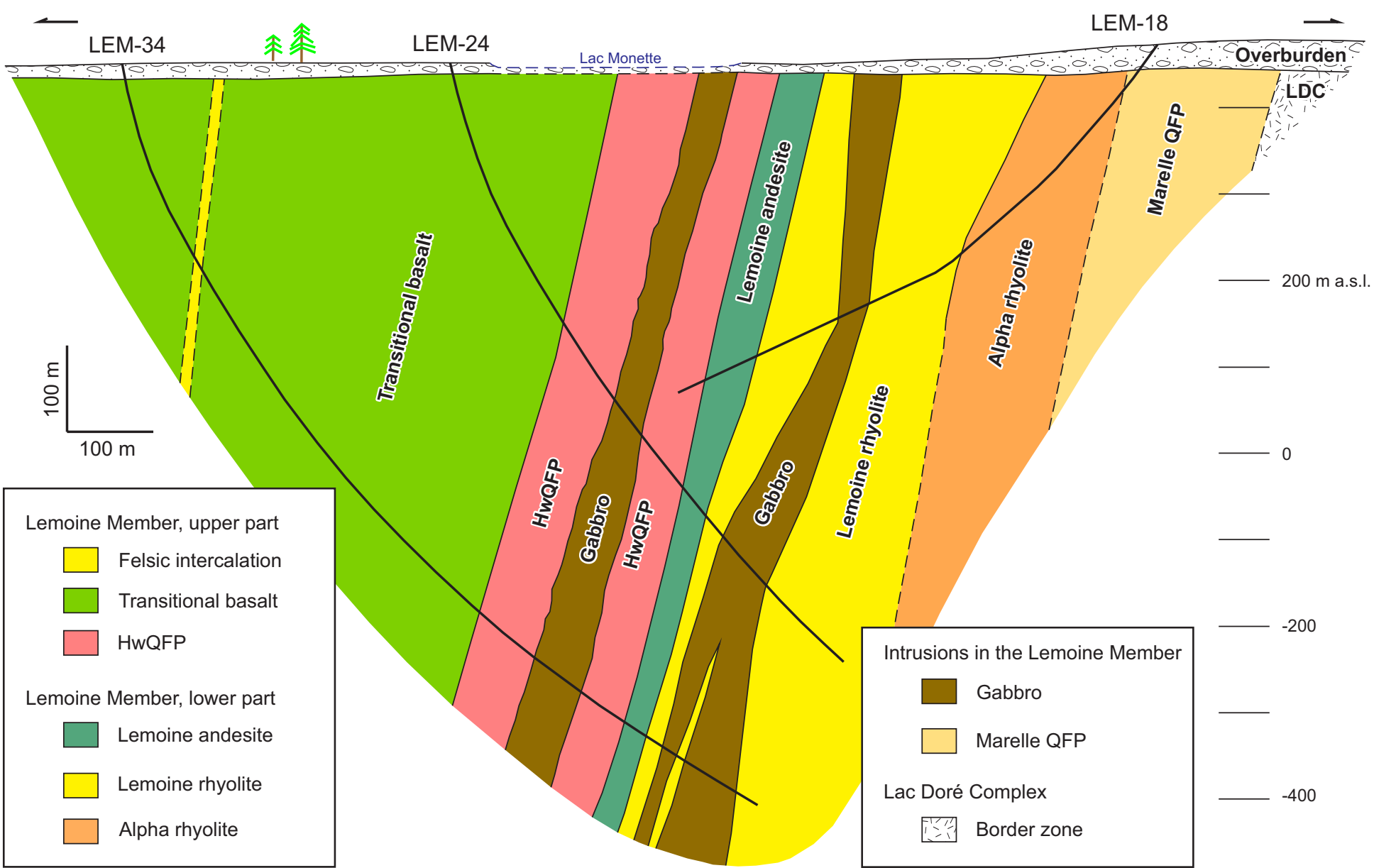

Fig. 3 


\section{a Alpha rhyolite}

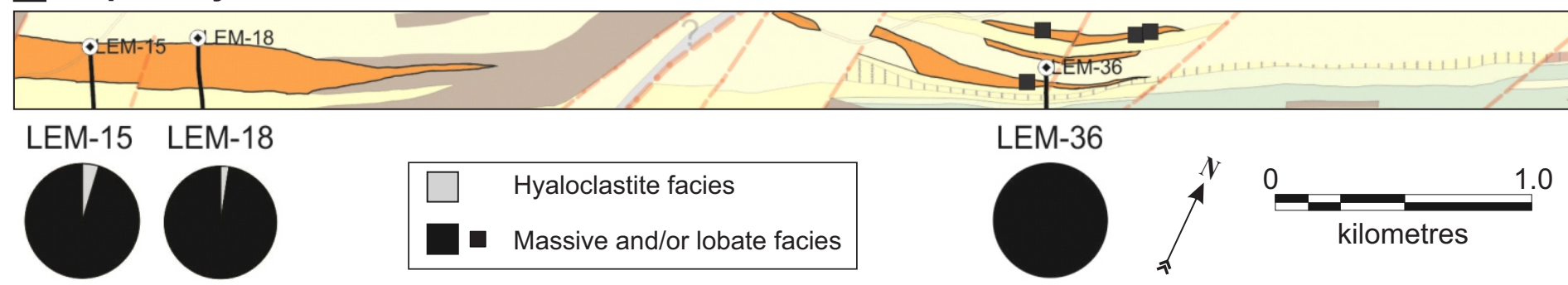

\section{b Lemoine rhyolite}
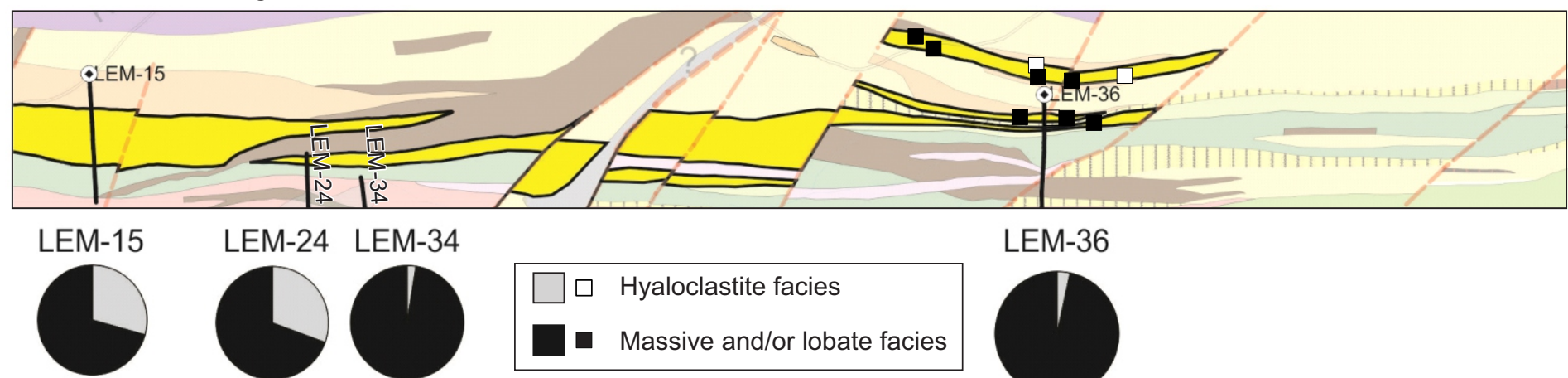

LEM-36

\section{Lemoine andesite}

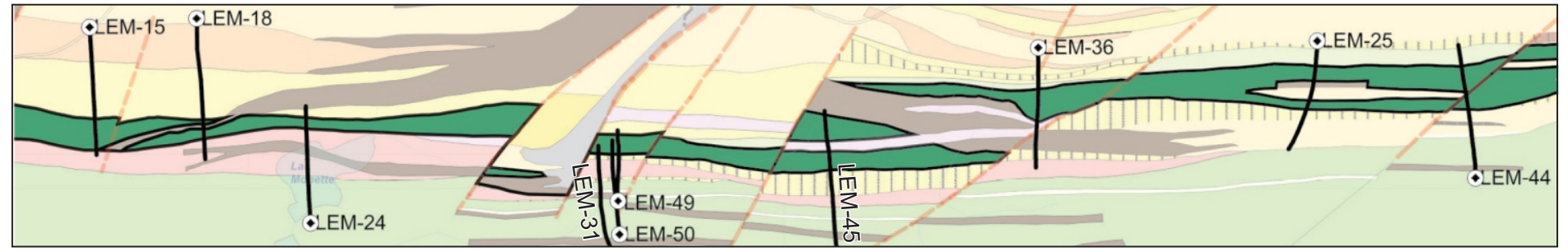

LEM-15 LEM-18 LEM-24
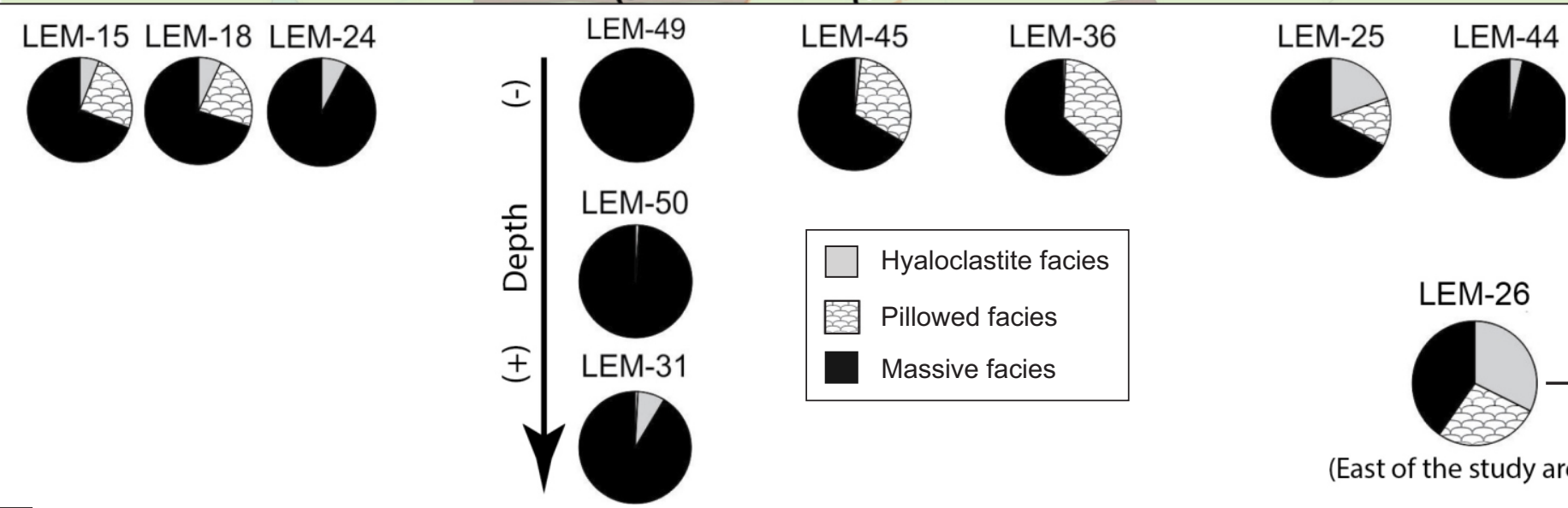

\section{d HwQFP}
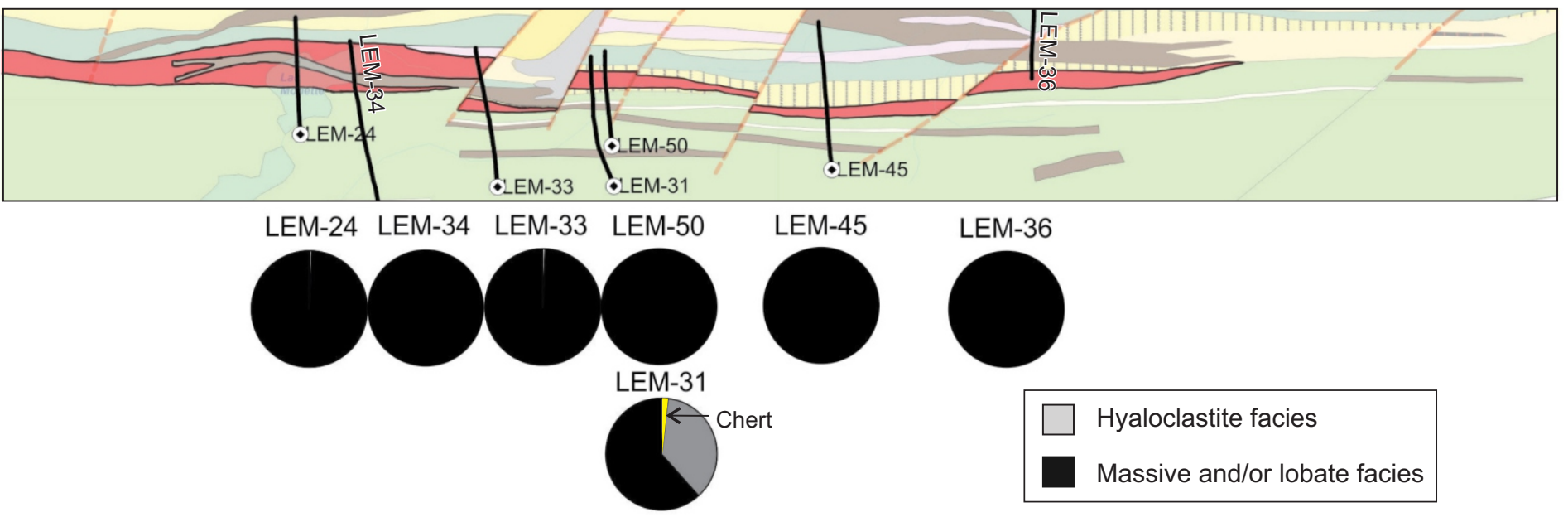

Hyaloclastite facies

Massive and/or lobate facies 

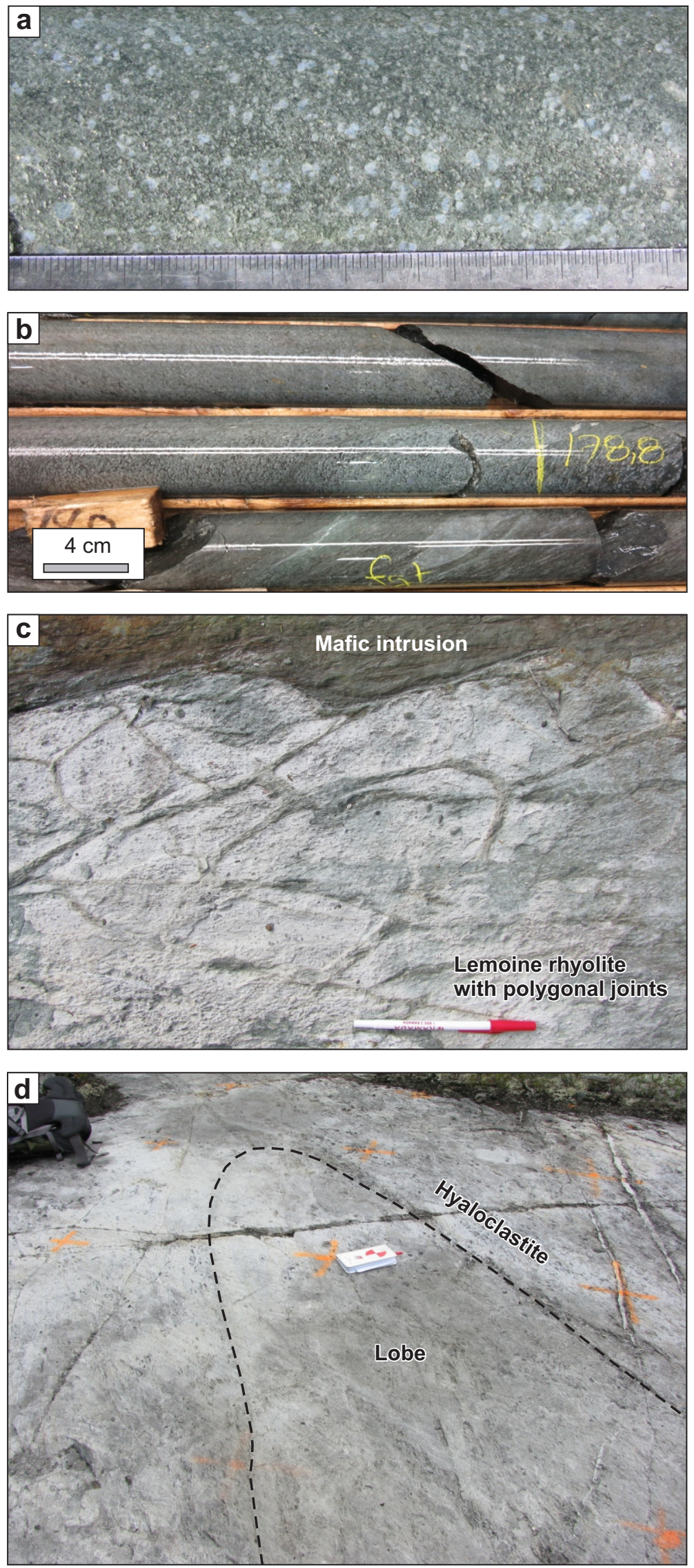
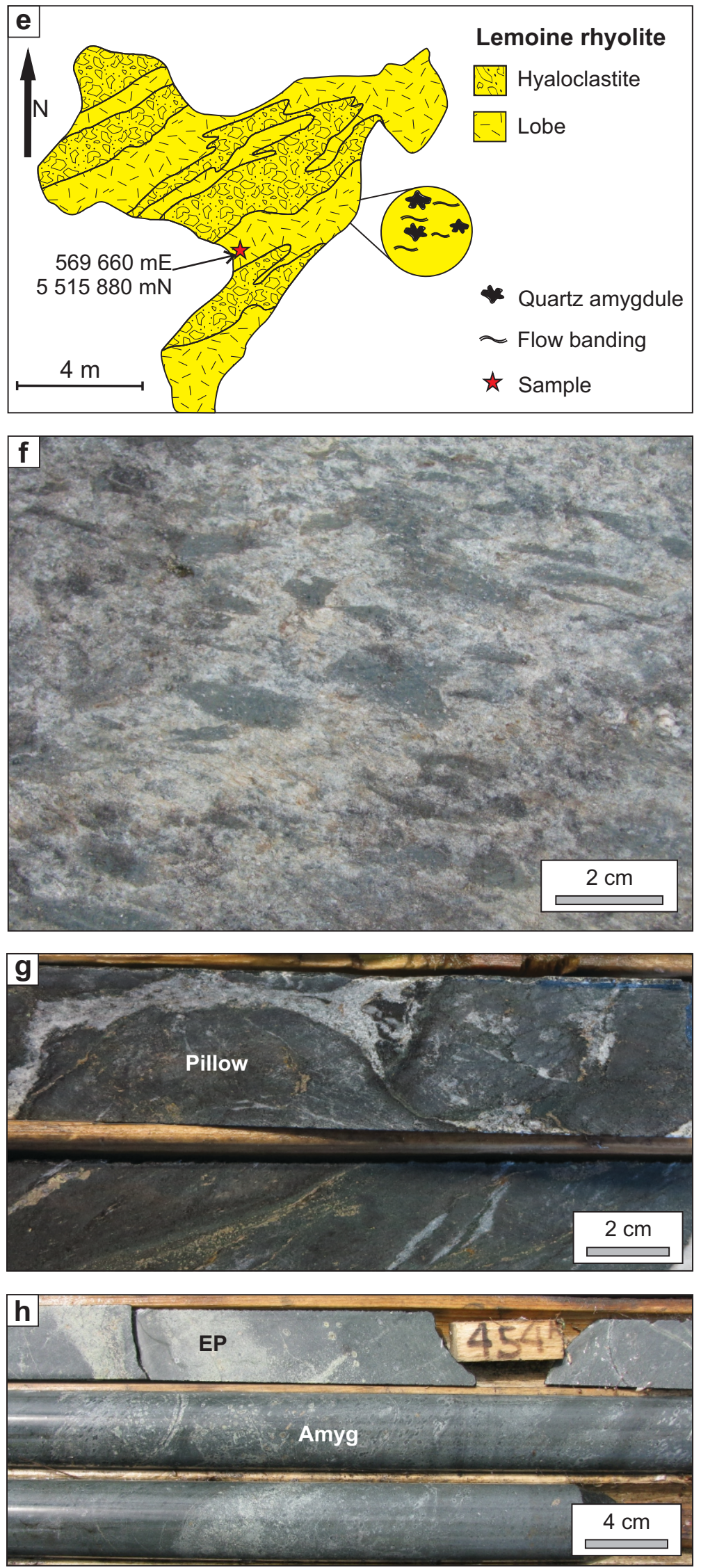

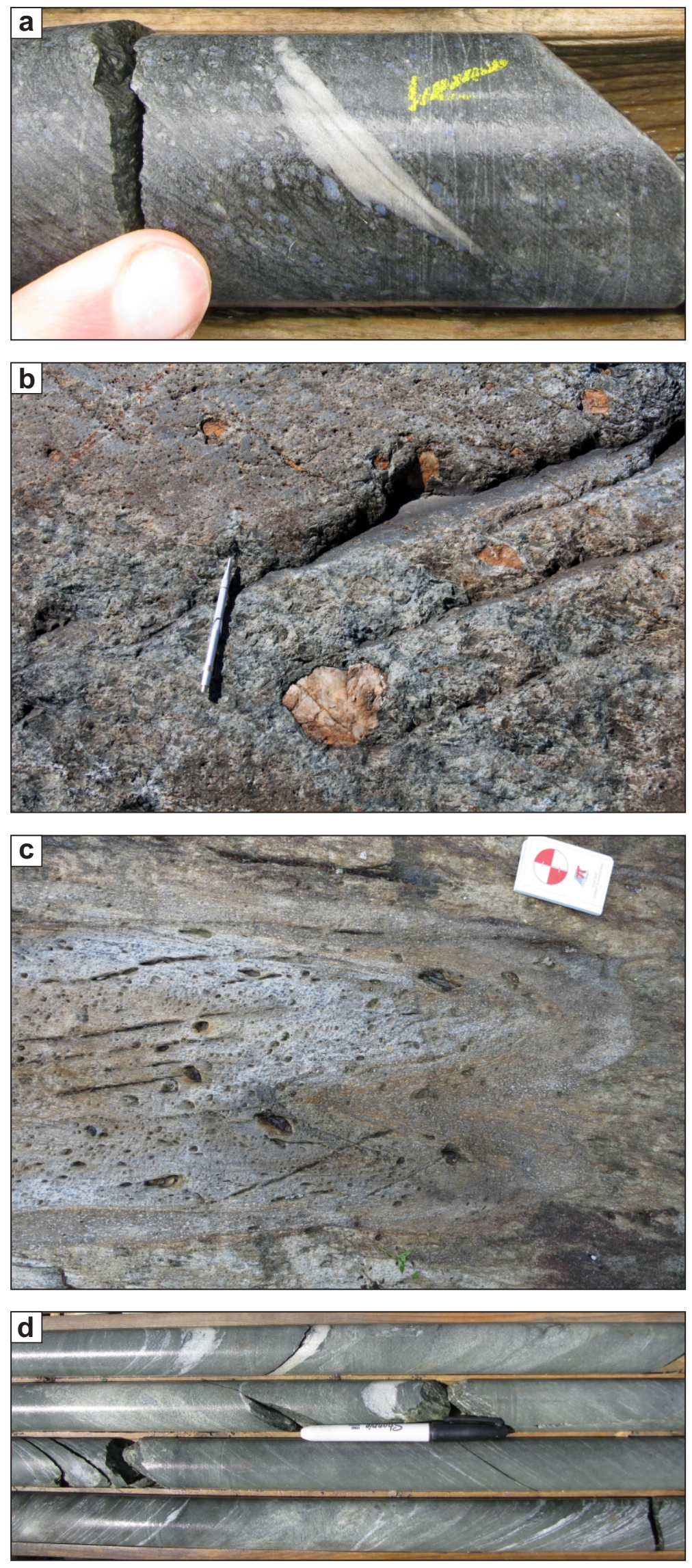
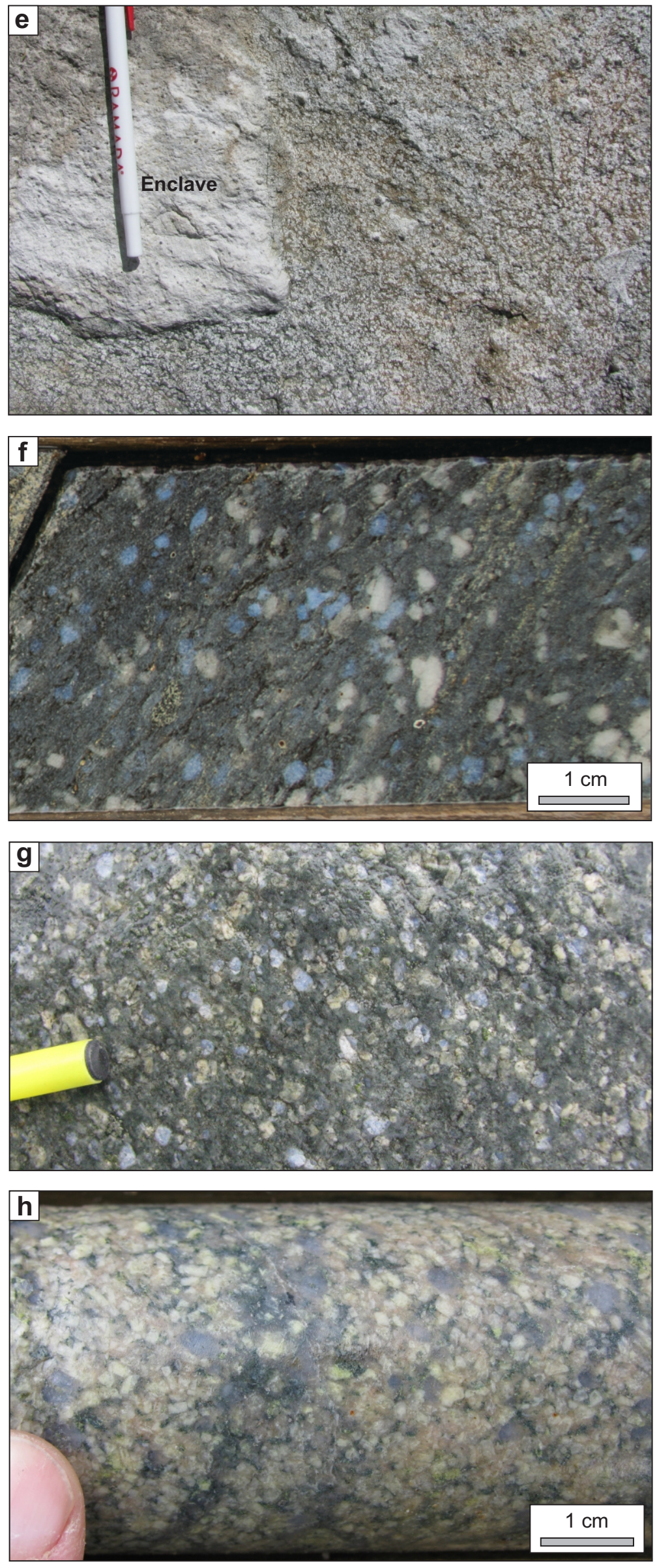

Fig. 6 

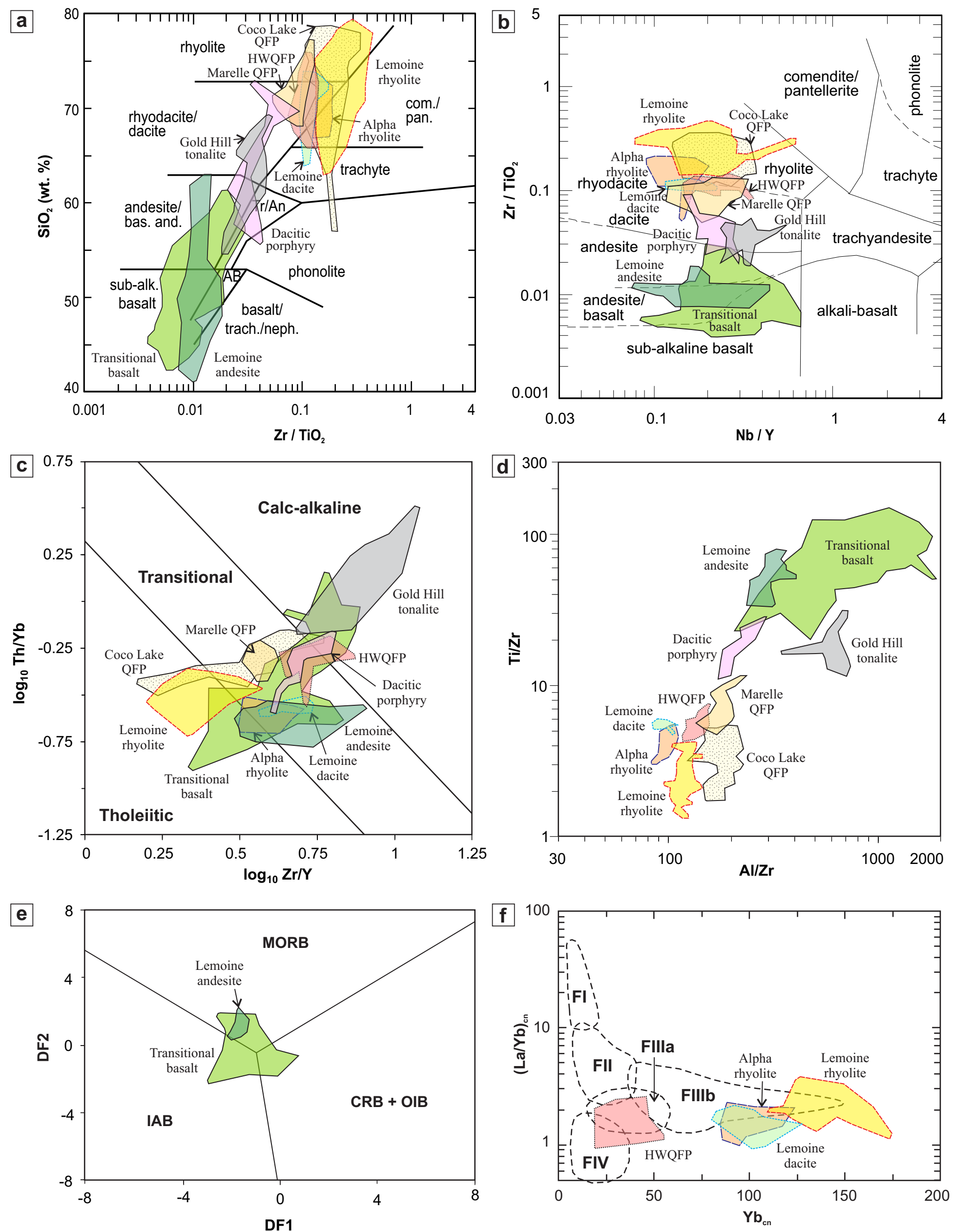

Fig. 7 


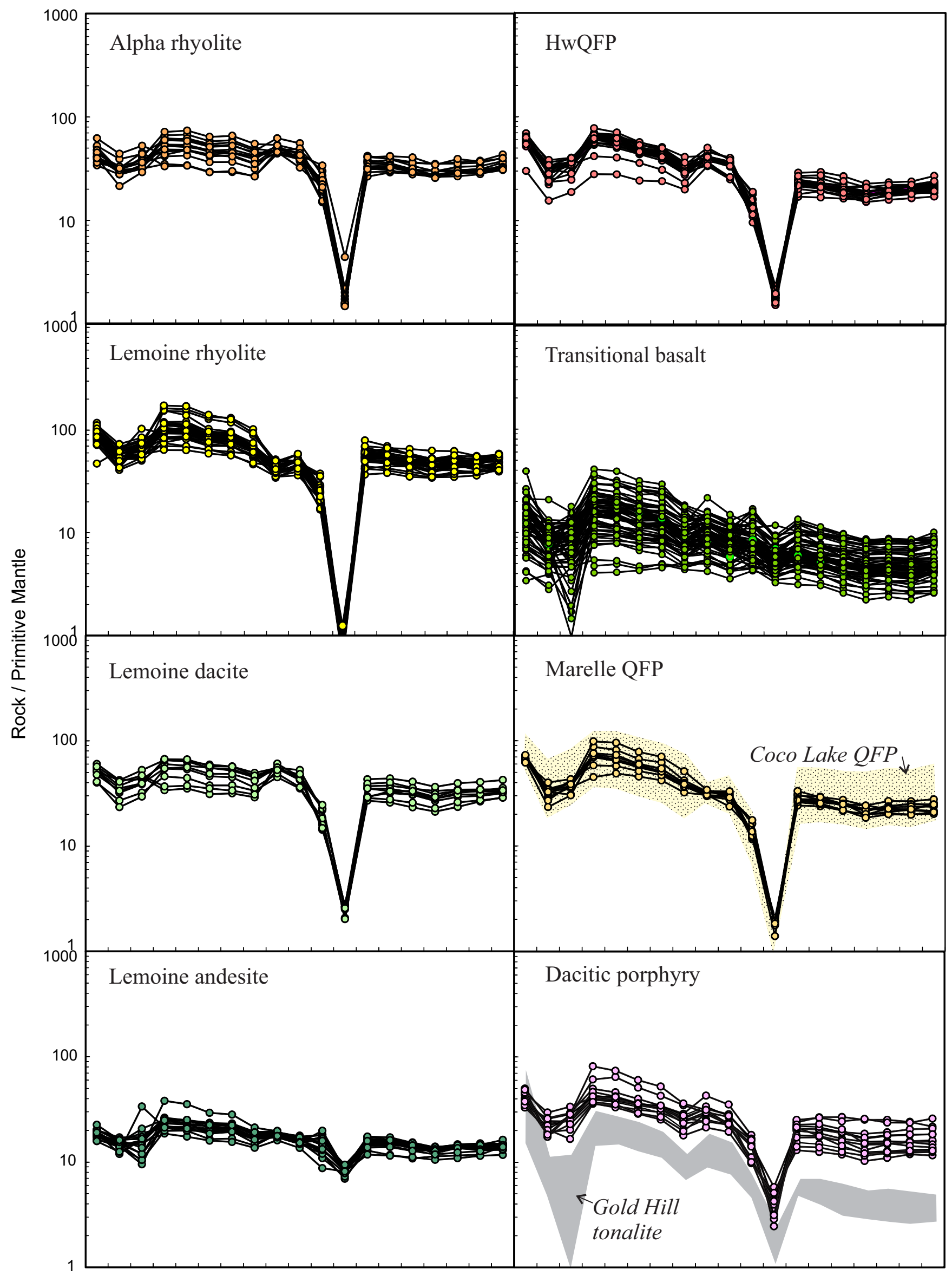

Th Nb Ta La Ce Pr NdSm Zr Hf Eu Ti Gd Tb Dy Y Er Yb Lu Th Nb Ta La Ce Pr NdSm Zr Hf Eu Ti Gd Tb Dy Y Er Yb Lu

Fig. 8 
a

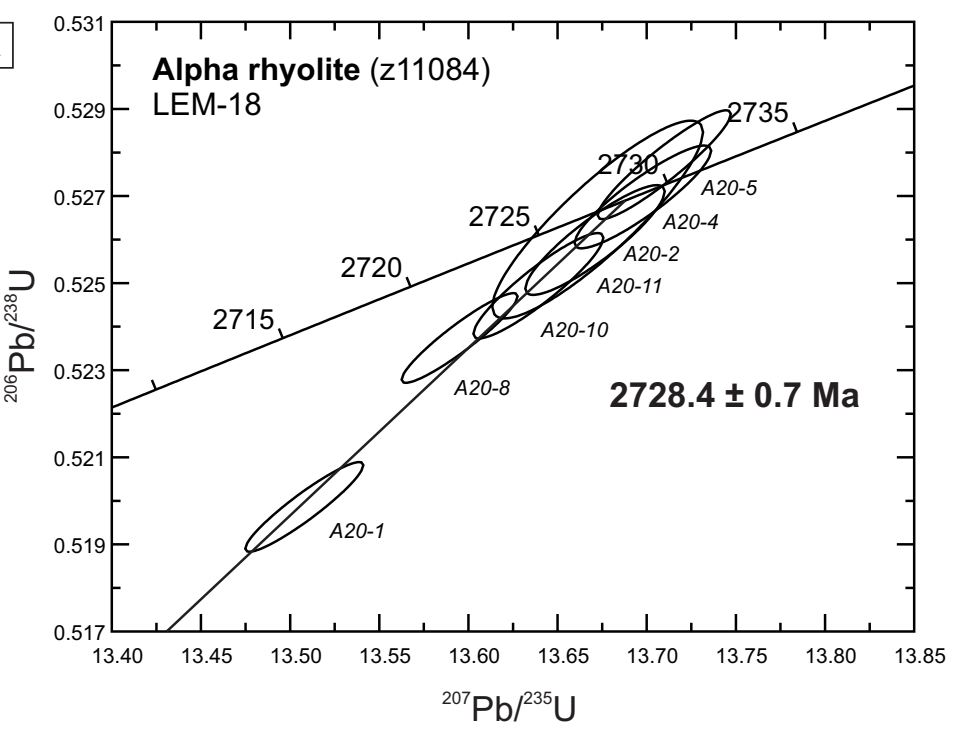

b

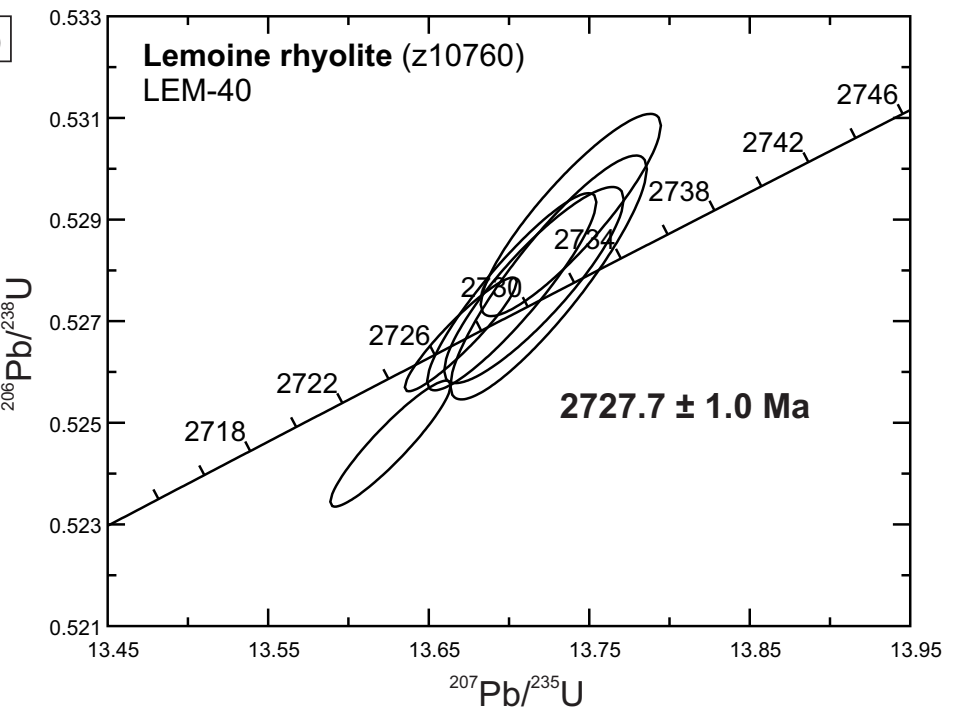

C

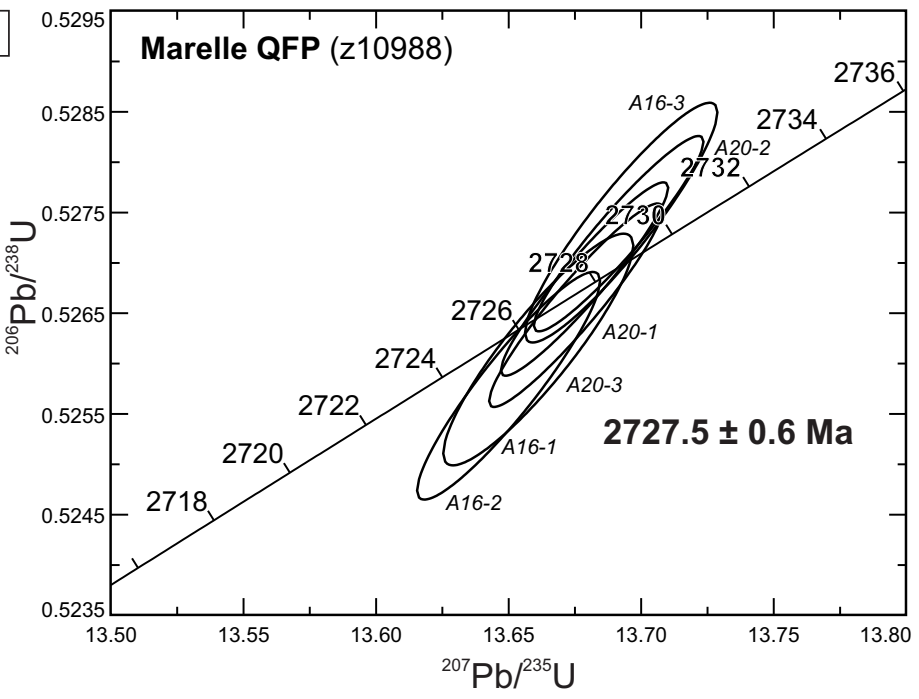

Fig. 9 

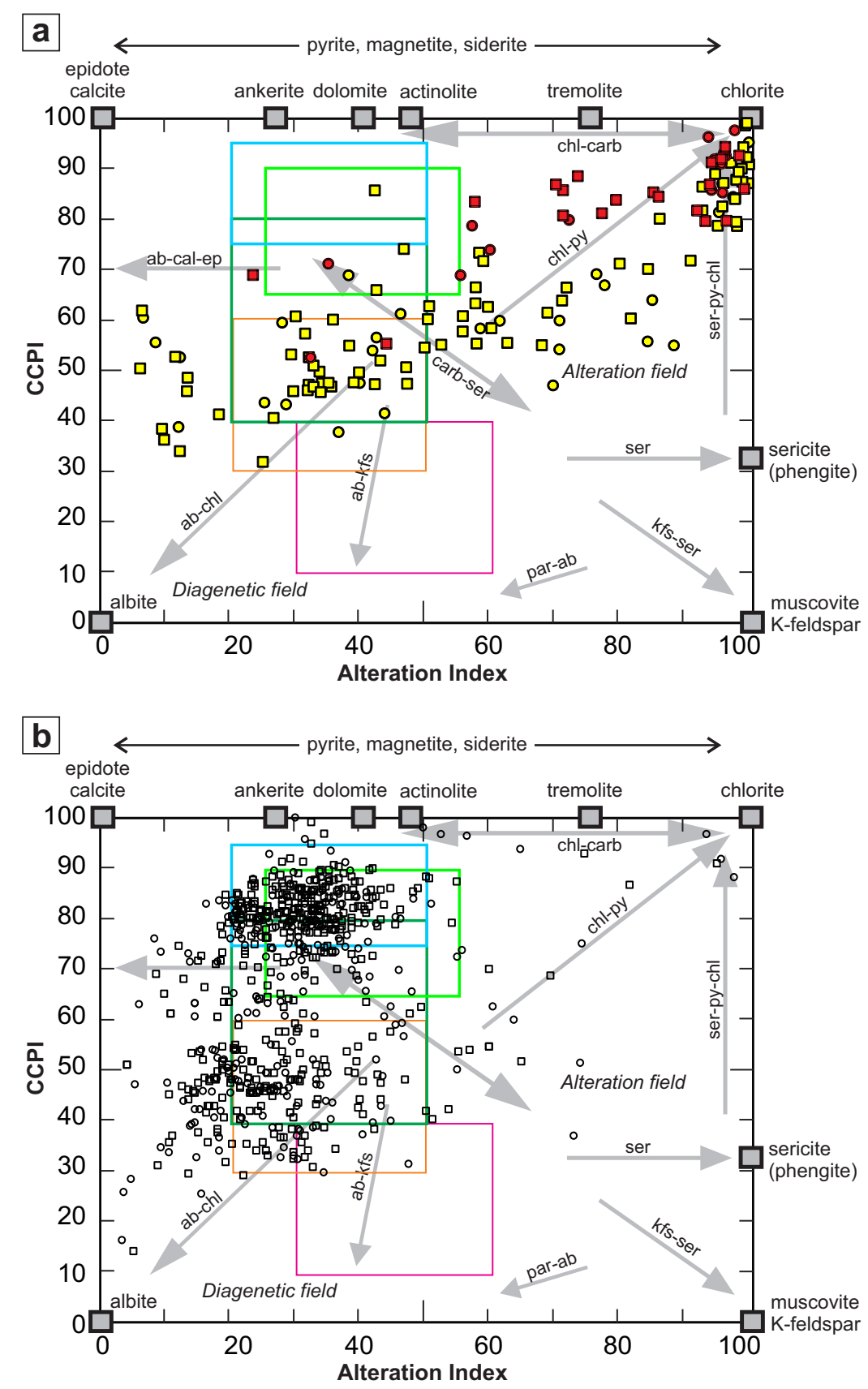

\begin{tabular}{|ll|}
\hline$\square \circ$ Lemoine rhyolite & Least altered boxes \\
$\square \circ$ Alpha rhyolite & Basalt (ridges) \\
$\square \circ$ All other units & Basalt (arcs) \\
& Andesite (arcs) \\
& Dacite (arcs) \\
& Rhyolite (arcs) \\
\hline
\end{tabular}

Fig.10 


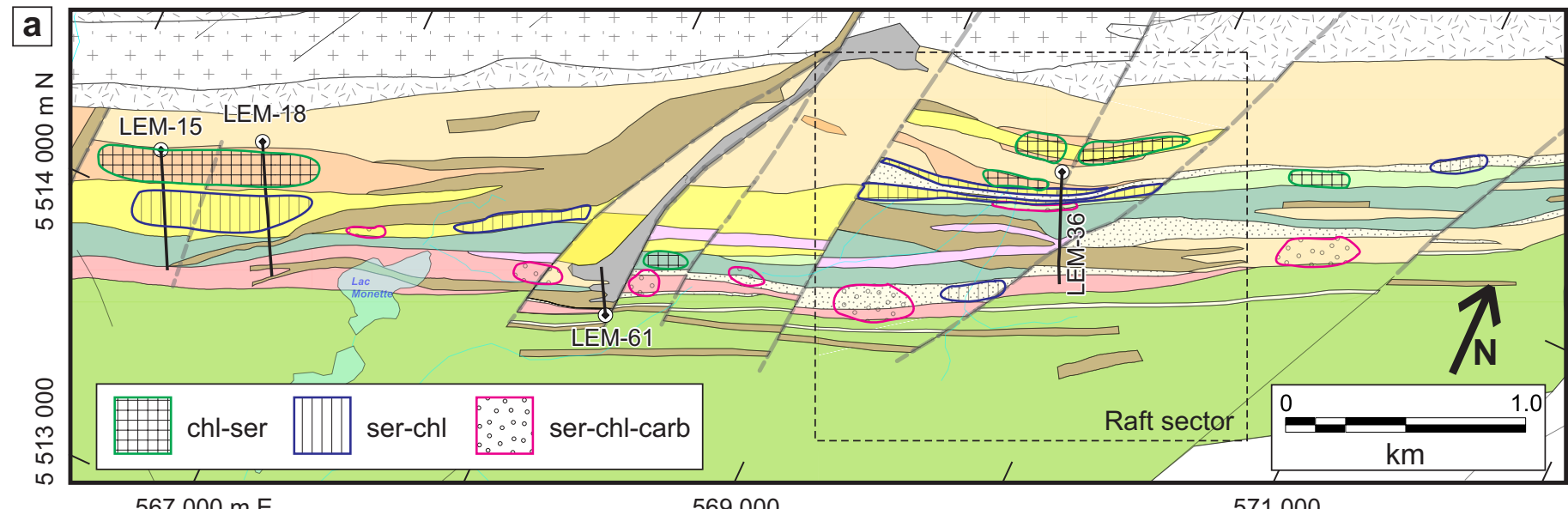
$567000 \mathrm{~m} \mathrm{E}$
569000
571000
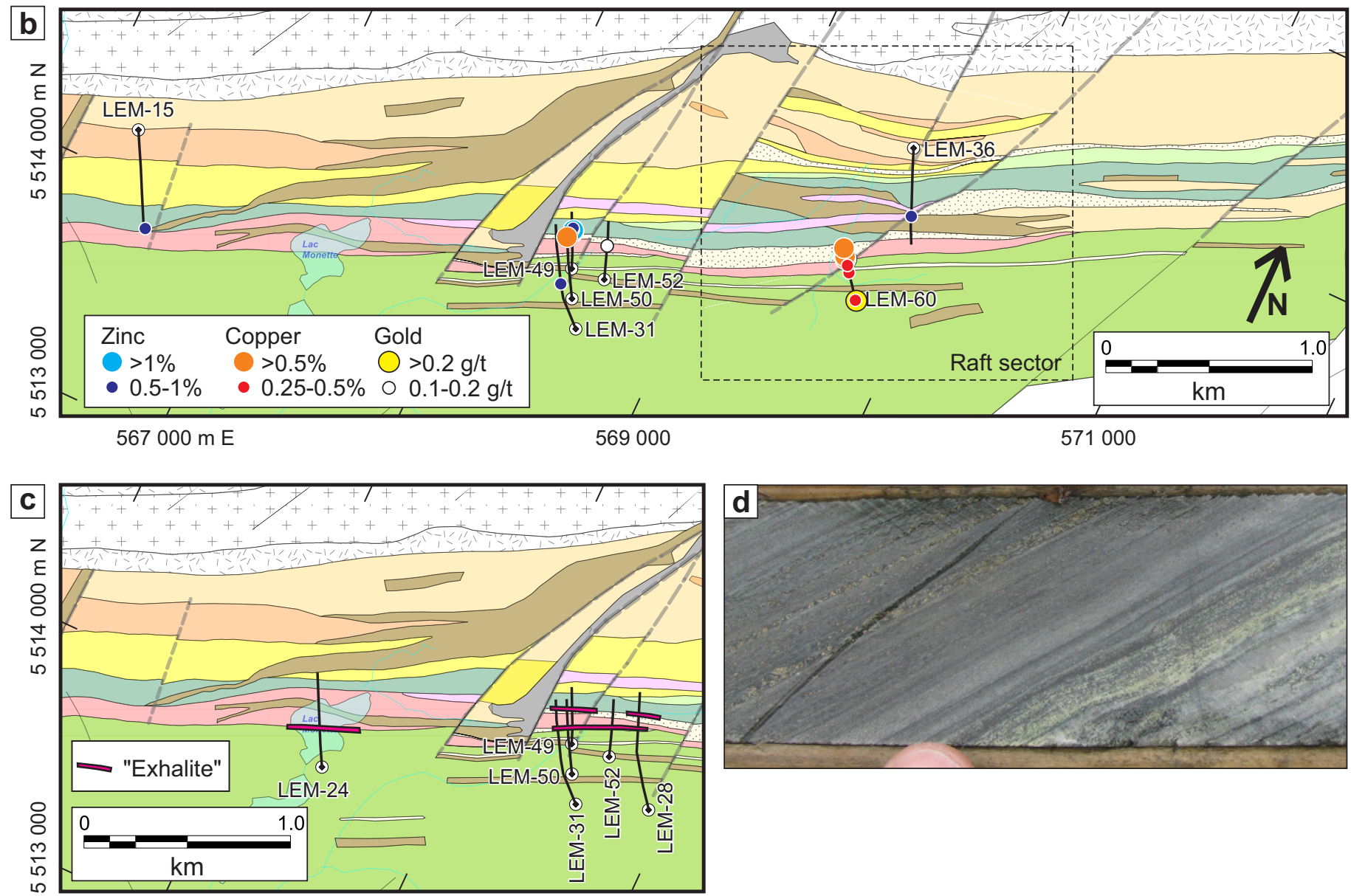

$567000 \mathrm{~m} \mathrm{E}$

569000

\section{Late Intrusions}

$\square$ Gold Hill tonalite

Waconichi Formation Intrusions

$\square$ Gabbro

Dacitic porphyry

Coco Lake QFP

Marelle QFP

\section{Waconichi Formation (cont.)}

\section{Upper part of the Lemoine Member}

$\square$ Felsic lenses

$\square$ Transitional basalt

Hangingwall QFP

\section{Lower part of the Lemoine Member}

$\square$ Lemoine andesite

$\square$ Lemoine dacite

$\square$ Lemoine rhyolite

$\square$ Alpha rhyolite

\section{Lac Doré Complex}

L- Border zone

+ Granophyre

[., Undifferentiated

Other

$\square$ Not mapped 

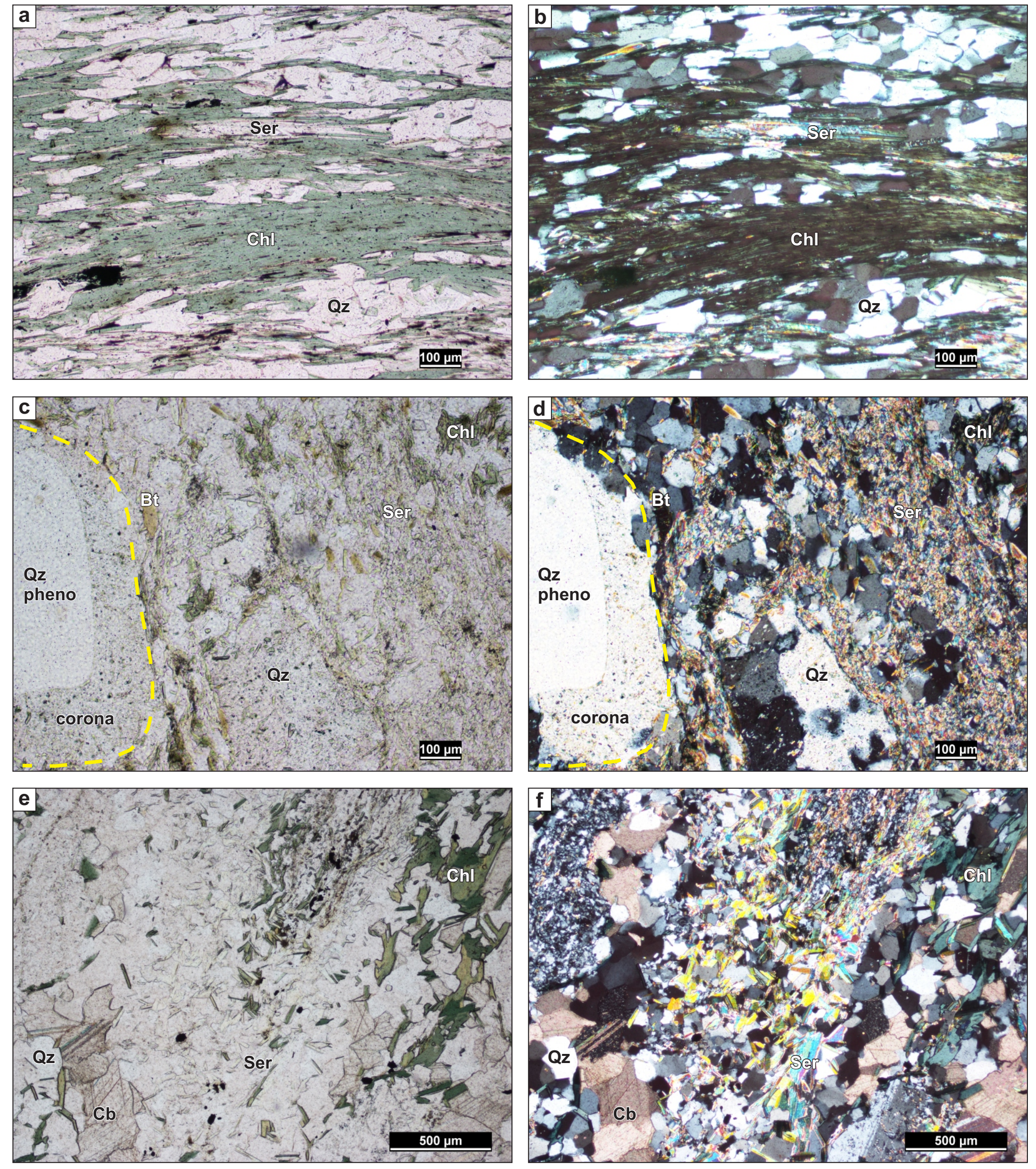

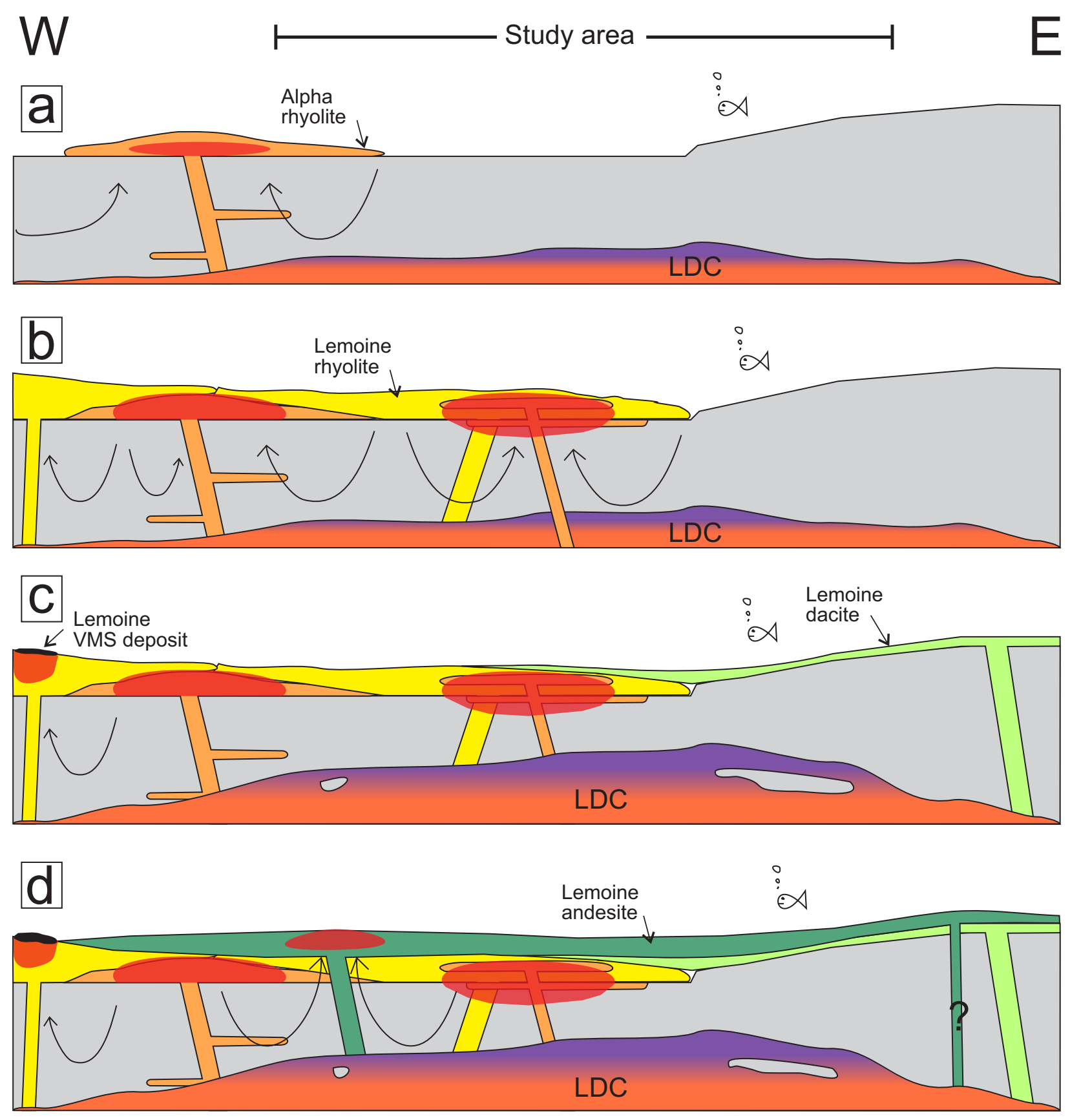

Fig. 13 

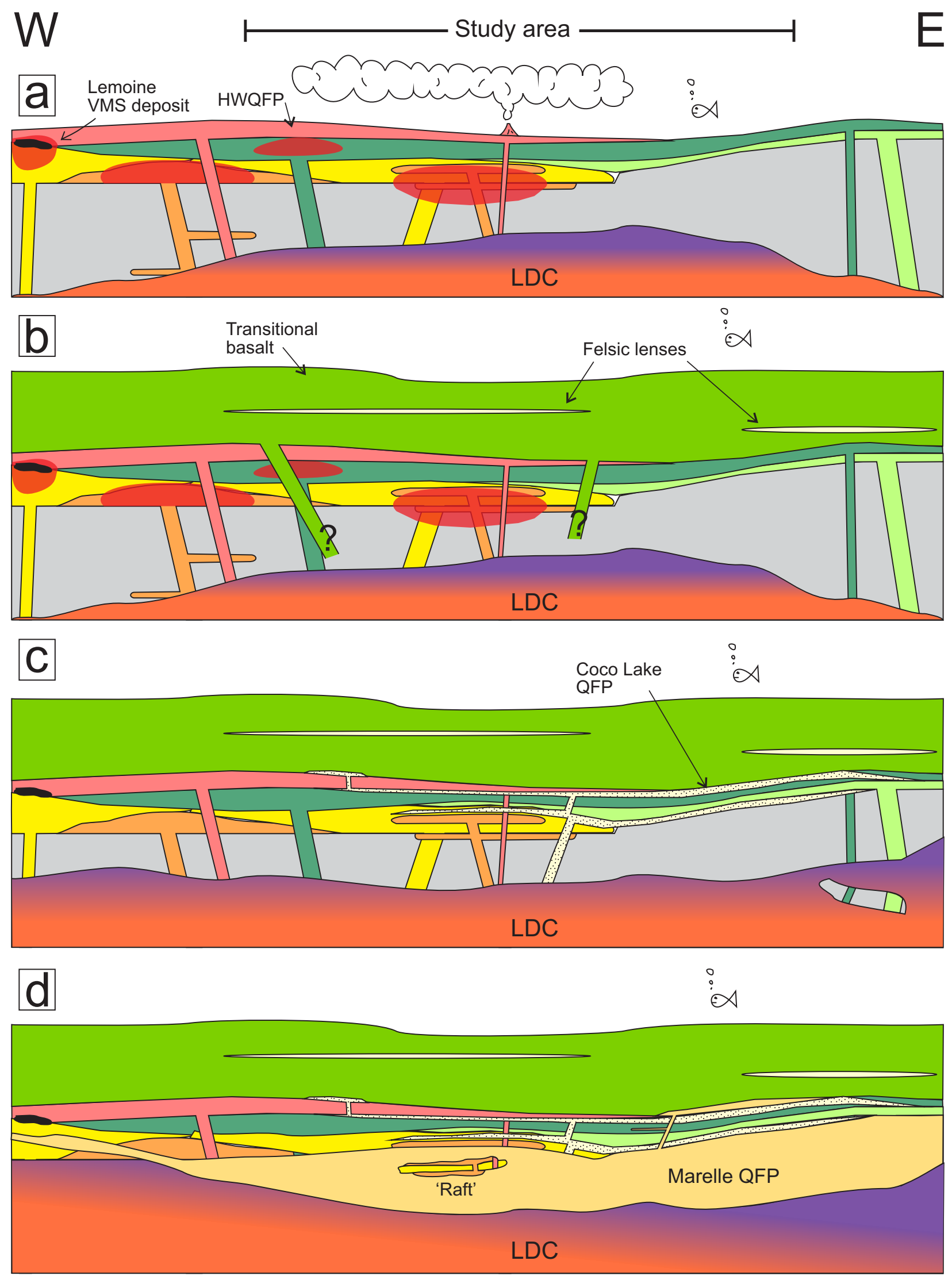

Fig. 14 